\title{
Corrosion-resistant Foamed Cements for Carbon Steels
}

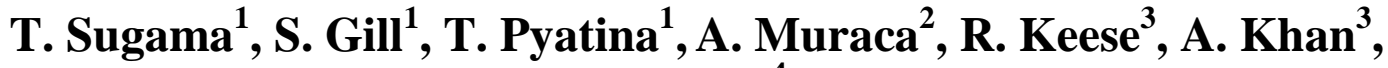 \\ D. Bour ${ }^{4}$ \\ ${ }^{1}$ Brookhaven National Laboratory, Upton, NY 11973 USA \\ ${ }^{2}$ William Peterson University, Wayne, NJ USA \\ ${ }^{3}$ Schlumberger, Sugar Land, TX USA \\ ${ }^{4}$ Geodynamic Limited, Milton, Australia
}

December 2012

\section{Sustainable Energy Technologies Department/Energy Conversion Group Brookhaven National Laboratory}

\section{U.S. Department of Energy DOE Office of Energy Efficiency and Renewable Energy}




\section{DISCLAIMER}

This report was prepared as an account of work sponsored by an agency of the United States Government. Neither the United States Government nor any agency thereof, nor any of their employees, nor any of their contractors, subcontractors, or their employees, makes any warranty, express or implied, or assumes any legal liability or responsibility for the accuracy, completeness, or any third party's use or the results of such use of any information, apparatus, product, or process disclosed, or represents that its use would not infringe privately owned rights. Reference herein to any specific commercial product, process, or service by trade name, trademark, manufacturer, or otherwise, does not necessarily constitute or imply its endorsement, recommendation, or favoring by the United States Government or any agency thereof or its contractors or subcontractors. The views and opinions of authors expressed herein do not necessarily state or reflect those of the United States Government or any agency thereof. 


\begin{abstract}
The cementitious material consisting of Secar \#80, Class F fly ash, and sodium silicate designed as an alternative thermal-shock resistant cement for the Enhanced Geothermal System (EGS) wells was treated with cocamidopropyl dimethylamine oxide-based compound as foaming agent (FA) to prepare numerous air bubble-dispersed low density cement slurries of $\leq 1.3 \mathrm{~g} / \mathrm{cm}^{3}$. Then, the foamed slurry was modified with acrylic emulsion (AE) as corrosion inhibitor. We detailed the positive effects of the acrylic polymer (AP) in this emulsion on the five different properties of the foamed cement: 1) The hydrothermal stability of the AP in $200^{\circ} \mathrm{C}$-autoclaved cements; 2 ) the hydrolysis-hydration reactions of the slurry at $85^{\circ} \mathrm{C} ; 3$ ) the composition of crystalline phases assembled and the microstructure developed in autoclaved cements; 4) the mechanical behaviors of the autoclaved cements; and, 5) the corrosion mitigation of carbon steel (CS) by the polymer. For the first property, the hydrothermal-catalyzed acid-base interactions between the AP and cement resulted in $\mathrm{Ca}$-or $\mathrm{Na}$-complexed carboxylate derivatives, which led to the improvement of thermal stability of the AP. This interaction also stimulated the cement hydration reactions, enhancing the total heat evolved during cement's curing. Addition of AP did not alter any of the crystalline phase compositions responsible for the strength of the cement. Furthermore, the APmodified cement developed the porous microstructure with numerous defect-free cavities of disconnected voids. These effects together contributed to the improvement of compressivestrength and -toughness of the cured cement. AP modification of the cement also offered an improved protection of CS against brine-caused corrosion. There were three major factors governing the corrosion protection: 1) Reducing the extents of infiltration and transportation of corrosive electrolytes through the cement layer deposited on the underlying CS surfaces; 2) inhibiting the cathodic reactions at the corrosion site of CS; 3) extending the coverage of cement over CS surfaces; and, 4) improving the adherence of the cement to CS surfaces. Thus, the CS's corrosion rate of 176 milli inch/per year (mpy) for $1 \mathrm{wt} \%$ FA-foamed cement without AP was considerably reduced to $69 \mathrm{mpy}$ by adding only $2 \mathrm{wt} \%$ AP. Addition of AP at $10 \mathrm{wt} \%$ further reduced this rate to $<10 \mathrm{mpy}$.
\end{abstract}




\section{Introduction}

The major thrust in assembling and constructing Enhanced Geothermal Systems (EGSs) lies in creating a hydrothermal reservoir in a hot dry rock stratum $\geq 200^{\circ} \mathrm{C}$, located at $\sim 3-10 \mathrm{~km}$ below the ground surface. In this operation, water at a low temperature of $\sim 25^{\circ} \mathrm{C}$ is pumped down the injection well to initiate the opening of existing fractures. Multi-injection wells are required to create a desirable network of permeable fractures. After that, a production well is installed within the fracture's network.

During the water injection, considerable attention must be paid to a significant differential between the temperatures at the bottom of the well and of the water from the injection well. This differential leads to a sudden temperature drop of $\geq \sim 180^{\circ} \mathrm{C}$ at the cement sheath surrounding the down-hole casing. Such a large thermal gradient due to the cooling effect of the injection water can give an undesirable thermal stress to the cement sheath, causing its potential failure that will entail a catastrophic blowout of well. To mitigate such temperature differential-caused stresses, the cement placed in EGS is required to possess adequate resistances to thermal cycle fatigue and thermal shock.

To deal with this issue and develop thermal shock-resistant cements, our previous study investigated the effectiveness of sodium silicate-activated Class F fly ash in improving such resistance of Secar $\# 80$ refractory cement [1]. We conducted a multiple air heating $\left(500^{\circ} \mathrm{C}\right)$-water $\left(25^{\circ} \mathrm{C}\right)$ cooling quenching cycle test for evaluating thermal shock resistance of $200^{\circ} \mathrm{C}$-autoclaved \#80/Class F fly ash/sodium silicate blend cements. The phase composition of the autoclaved \#80/Class F fly ash blend cements comprised four crystalline hydration products, boehmite, katoite, hydrogrossular, and hydroxysodalite, which were responsible for strengthening the cement. Among them, the hydroxysodalite was transformed into nano-scale crystalline carbonated sodalite during this cycle test. This phase transition not only played a pivotal role in densifying cementitious structure and in sustaining the original compressive strength developed after autoclaving, but also it improved the thermal shock resistance of \#80 cement.

Another critical issue in formulating well casing cements is the density of the cement slurry. Lowdensity cement slurries are required to avoid fracturing weak unconsolidated rock formations and lost circulation in geothermal wells. However, our study on the properties of fine air bubble-incorporated foamed cement slurry strongly suggested that the shortcoming of this hydrothermally cured foamed cement was its low protection of carbon steel (CS) casings against corrosion, compared against that of non-foamed cement [2].

As is well documented [3-8], when the surfaces of CS come in contact with alkaline pore solution of $\mathrm{pH}>12$ in Ordinary Portland Cement (OPC), they form a passive Fe oxide film that protects the CS against corrosion. However, the stability of this passivation layer depends primarily on the surrounding environment and exposure conditions. In geothermal environments, there are two major chemical factors governing the destruction of the corrosion-preventing passive film and initiation of casing corrosion: One is the prevalence of carbonation-related carbonate ions; and, the other is the attack of chloride ions on the passive film in which the risk of corrosion of CS commonly is equated with the chloride content, usually taking onto account the chloride/hydroxyl $\left[\left(\mathrm{Cl}^{-}\right) /\left(\mathrm{OH}^{-}\right)\right]$ratio. For the former factor, carbon dioxide $\left(\mathrm{CO}_{2}\right)$ can penetrate through the pores in OPC, and then react with water to form carbonic aid, $\mathrm{H}_{2} \mathrm{CO}_{3}$, thereby lowering the $\mathrm{pH}$ of the pore solution in OPC layers adjacent to the CS's surfaces. Thus, such depassivation promotes the localized corrosion of CS, and then the corrosion products 
formed on CS's surface engender a volumetric expansion of CS, generating a stress cracking and the spallation of OPC sheath at the interfacial boundary regions between the OPC and CS-based well casing. Further, the failure of OPC sheath at the initial stage of CS's corrosion not only accelerates its corrosion rate, but also shortens the service lifespan of casings; such impairment of the integrity of well structure entails the need for costly repairs and restorative operations including re-drilling to reconstruct the damaged well, and occasionally necessitates the assemblage of new wells. To avoid such a catastrophic failure of well structure, very expensive metal components incurring a high capital investment, for example, titanium alloy, stainless steel, and inconel components frequently are employed in fabricating corrosion-preventing well casings. Thus, the ideal approach to reducing capital investments along with operational and maintenance costs in EGS wells is by using inexpensive CS-based casings covered with corrosion-inhibiting well cementing materials. In this concept, the cementing materials play a pivotal role in extending the lifecycles of the CS-made casings and in retaining the well's integrity, so eventually lowering the costs of electricity generated from geothermal power plants.

Presently, there are two prevalent methods to minimize and alleviate the corrosion of CS $[9,10]$ : One way is to apply coatings to CS's surface as cathodic protection; the other is to use anodic corrosion inhibitors. Our previous work on the former method [11] centered on evaluating the ability of a hybrid coating system consisting of a water-borne acrylic emulsion as the matrix and calcium aluminate cement as the hydraulic filler to mitigate the corrosion of $\mathrm{CS}$ in $\mathrm{CO}_{2}$-laden geothermal environments at $250^{\circ} \mathrm{C}$. We found that two major factors significantly contributed to inhibiting the corrosion of CS in such a hydrothermal environment: One was the hydrothermally stable reaction products formed by the interactions between acrylic polymer and cement; the other was the development of a dense microstructure by the combination of well-formed calcite and boehmite crystals with polymer-cement reaction products.

Based upon this information, the thermal shock-resistant cement (TSRC) developed by BNL would be required to possess two indispensable properties: First, the density of its slurry must be lowered; and, second, the ability of hydrothermally cured TSRC to protect the CS casing against corrosion must be assured. Hence, we formulated air bubble-foamed TSRC for preparing low density cement slurry at room temperature, and then modified it with acrylic-based polymer emulsion as corrosion inhibiting additive to lessen the corrosion of CS under a hydrothermal environment at $200^{\circ} \mathrm{C}$. In characterizing the polymer-modified foamed TSRC, our study focused on nine objectives: 1) Measuring the changes in the density of foamed and non-foamed cement slurries as function of acrylic emulsion (AE) content; 2) identifying the reaction product formed by interactions between cement and $\mathrm{AE}$ at $200^{\circ} \mathrm{C}$ and assessing the thermal stability of the reaction product; 3 ) characterizing the hydrolysis-hydration reaction behaviors of the cement slurries at $85^{\circ} \mathrm{C}$ and investigating the total energy evolved in this reaction of slurries; 4) determining the compressive-strength and -toughness of $200^{\circ} \mathrm{C}$-autoclaved cements; 5) identifying the crystalline phases formed in the cement after autoclaving at $200^{\circ} \mathrm{C}$; 6) exploring the microstructure developed within cements; 7) measuring the conductivity of corrosive ions through the cement layers deposited on the CS's surfaces by the AC electrochemical impedance spectroscopy (EIS); 8) evaluating the ability of cement to reduce the corrosion rate of CS using the DC electrochemical potentiodynamic polarization test on CS covered with cements; and, 9) assessing the extent of adherence of the cements to the underlying CS. 
Integrating all these data obtained form the objectives described above would clarify the potential of the AE-modified foamed TSRC as corrosion-alleviating well cements for CS casings in EGS environment of $200^{\circ} \mathrm{C}$.

\section{Experimental procedures}

\subsection{Materials}

Class F fly ash was obtained from Boral Material Technologies, Inc., and its chemical composition detected by micro energy-dispersive X-ray spectrometer ( $\mu$ EDX) was as follows; $50.4 \% \mathrm{SiO}_{2}, 34.8 \% \mathrm{Al}_{2} \mathrm{O}_{3}, 7.1 \% \mathrm{Fe}_{2} \mathrm{O}_{3}, 3.1 \% \mathrm{~K}_{2} \mathrm{O}, 2.7 \% \mathrm{CaO}, 1.6 \% \mathrm{TiO}_{2}$, and $0.4 \% \mathrm{SO}_{3}$. A sodium silicate granular powder under the trade name "Metso Beads 2048," supplied by the PQ Corporation was used as the alkali activator of Class F fly ash. Its chemical composition was $50.5 \mathrm{wt} \% \mathrm{Na}_{2} \mathrm{O}$ and $46.6 \mathrm{wt} \% \mathrm{SiO}_{2}$. Secar \#80, supplied by Kerneos Inc. was used as calcium aluminate refractory cement. The X-ray powder diffraction (XRD) data showed that the crystalline compounds of Class $\mathrm{F}$ fly ash had three major phases, quartz $\left(\mathrm{SiO}_{2}\right)$, mullite $\left(3 \mathrm{Al}_{2} \mathrm{O}_{3} .2 \mathrm{SiO}_{2}\right)$, and hematite $\left(\mathrm{Fe}_{2} \mathrm{O}_{3}\right)$, while \#80 encompassed three crystalline phases, corundum $\left(\alpha-\mathrm{Al}_{2} \mathrm{O}_{3}\right)$, calcium monoaluminate $\left(\mathrm{CaO} \cdot \mathrm{Al}_{2} \mathrm{O}_{3}, \mathrm{CA}\right)$, and calcium dialuminate $\left(\mathrm{CaO} .2 \mathrm{Al}_{2} \mathrm{O}_{3}, \mathrm{CA}_{2}\right)$.

The AISI 1008 cold rolled steel test panel according to ASTM D 609C was used as carbon steel (CS) substrate, supplied by ACT Test Panels, LLC. Alkaline cleaner \#4429, supplied from American Chemical Products, was used to remove any surface contaminants of CS. This cleaner was diluted with deionized water to prepare $5 \mathrm{wt} \%$ cleaning solution.

Acrylic emulsion (AE) under the trade name "HYCAR® 26-0688," supplied by Lubrizol, was employed as the corrosion-inhibiting additive for cement. This water-dispersible AE consisted of $49.5 \mathrm{wt} \%$ acrylic polymer (AP) as its solid state and $41.5 \mathrm{wt} \%$ aqueous medium, and its $\mathrm{pH}$ was 2.32 .

Halliburton supplied the cocamidopropyl dimethylamine oxide-based foaming agent (FA) under the trade name "ZoneSealant 2000."

We adapted the dry blend cement formula consisting of $60 \mathrm{wt} \%$ \#80 and $40 \mathrm{wt} \%$ Class F fly ash in this study. The sodium silicate of $6.2 \%$ by total weight of the blended cement was added to $60 / 40$ \#80/Class F fly ash ratio to prepare the one dry mix cement component. The amounts of AP used to modify the cement were $2,5,10$, and $15 \%$ by total weight of this dry mixture. In preparing the foamed AP-containing cements, 1.0 and $2.0 \%$ FA by total weight of water was added to AE-dispersed cement slurry. The following sequence was employed to make the foamed AP-containing cement slurry: First, the proper amount of water-miscible FA was blended in water, followed by incorporating the proper amount of AE into it; second, this waterbased solution was added to a dry cement component to prepare a slurry; namely, the water/(cement $+\mathrm{AE})[\mathrm{W} /(\mathrm{C}+\mathrm{AE})]$ ratios for $0,2,5,10$, and $15 \mathrm{wt} \% \mathrm{AP}$-modified cements were $0.44,0.38,0.36,0.26$, and 0.22 , receptivity; and, finally, the AP-containing foamed cement

slurry was mixed thoroughly in a shear-blender for $30 \mathrm{sec}$. This shear mixing made it possible to 
prepare aerated slurry containing a vast number of air bubbles; this mixing transformed the original stiff slurry into a smooth creamy one.

The surfaces of the $65 \mathrm{~mm}$ x $65 \mathrm{~mm}$ CS test panels were coated with the foamed AP-containing cements in the following sequence: First, the "as-received" test panels were immersed in a $5 \mathrm{wt} \%$ alkali-cleaning solution at $40^{\circ} \mathrm{C}$ for $10 \mathrm{~min}$; second, alkali-cleaned panels' surfaces were rinsed with a tap water at $25^{\circ} \mathrm{C}$, and dried for 24 hours in air at room temperature; third, the panels were dipped into a soaking bath of cement slurries at room temperature, and withdrawn slowly; fourth, the cement slurry-covered panels then were left for 3 days at room temperature, allowing the slurry to convert into a solid layer; and, finally, the cement-coated panels were autoclaved for 24 hours at $200^{\circ} \mathrm{C}$ before conducting the electrochemical corrosion tests. The thickness of all the cement layers depositing on the underlying CS's surfaces ranged from $\sim 1.0$ to $\sim 1.4 \mathrm{~mm}$.

\subsection{Measurements}

The density, $\mathrm{g} / \mathrm{cm}^{3}$, of the foamed cement slurries was determined using the fluid density container. Then, the slurries were poured in cylindrical molds (20 $\mathrm{mm}$ diam. and $40 \mathrm{~mm}$ long) and left for 3 days at room temperature before determining their compressive-strength and toughness. Thereafter, the hardened foamed cements were removed from the mold and autoclaved at $200^{\circ} \mathrm{C}$ for 24 hours, then left for 24 hours at room temperature.

TAM Air Isothermal Microcalorimeter was used to investigate the hydrolysis-hydration reaction behaviors of cement slurries and to determine the total heat flow evolved during this reaction at $85^{\circ} \mathrm{C}$. The changes in compressive-strength and -toughness of the $200^{\circ} \mathrm{C}-24 \mathrm{hr}$-autoclaved cements as a function of AP's content were obtained using Instron Model 5967. The reaction products between the AP and cement at hydrothermal temperatures of $85^{\circ}$ and $200^{\circ} \mathrm{C}$ were identified using Fourier Transform Infrared Spectroscopy (FT-IR), and then the thermal stability of identified reaction products was surveyed using Thermo Gravimetric Analysis (TGA) at the heating rate of $20^{\circ} \mathrm{C} / \mathrm{min}$ in a $\mathrm{N}_{2}$ flow. Changes in the crystalline phase compositions of $200^{\circ} \mathrm{C}$ autocalved foamed cements modified with different contents of AP were studied by X-ray diffraction (XRD). Alterations of the microstructure developed in foamed cements at $200^{\circ} \mathrm{C}$ by AP were explored using the High-Resolution Scanning Electron Microscopy (HR-SEM). The adherence behaviors of AP-modified and non-modified foamed cements to CS's surface was surveyed using the $\mu$ EDX. DC electrochemical testing for corrosion of the underlying CS was performed with the EG\&G Princeton Applied Research Model 326-1 Corrosion Measurement System. In this assessment, the cement-coated CS specimen was mounted in a holder, and then inserted into an EG\&G Model K47 electrochemical cell containing a 1.0 M sodium chloride electrolyte solution. The test was conducted in air at $25^{\circ} \mathrm{C}$, on an exposed surface area of 1.0 $\mathrm{cm}^{2}$. The polarization curves were measured at a scan rate of $0.5 \mathrm{mVs}^{-1}$ in the corrosion potential ranging from -0.05 to $-0.75 \mathrm{~V}$. AC electrochemical impedance spectroscopy (EIS) was used to evaluate the ability of the cement layers to protect the CS from corrosion. The coated CS specimens with a surface area of $13 \mathrm{~cm}^{2}$ were mounted in a holder, and then inserted into an electrochemical cell containing a $1.0 \mathrm{M}$ sodium chloride electrolyte at $25^{\circ} \mathrm{C}$, and single-sine technology with an input $\mathrm{AC}$ voltage of $10 \mathrm{mV}$ (rms) was employed over a frequency range of $10^{5}$ to $10^{-3} \mathrm{~Hz}$. To estimate the protective performance of the cements, the pore resistance, $R_{p}$, 
$\left(\mathrm{ohm}-\mathrm{cm}^{2}\right)$ was determined from the plateau in Bode-plot scans occurring in low frequency regions.

\section{Results and discussion}

\subsection{Density of slurries}

Figure 1 shows the changes in density of foamed slurries as a function of AP content. Without any AP, the density of the non-foamed cement slurry denoted as $0 \%$ FA was $1.86 \mathrm{~g} / \mathrm{cm}^{3}$ representing the common well cement slurries. This density drastically dropped by $31 \%$ to 1.29 $\mathrm{g} / \mathrm{cm}^{3}$, as $1 \%$ FA was added to it. A further density reduction to $0.69 \mathrm{~g} / \mathrm{cm}^{3}$ was observed after adding $2 \% \mathrm{FA}$, emphasizing that this FA is very effective in reducing the density of this specific blend cement slurry consisting of \#80, Class F fly ash and sodium silicate. The density of the original non-foamed slurry gradually declined with an increasing content of AP; adding $15 \mathrm{wt} \%$ AP reduced the slurry's density to $1.71 \mathrm{~g} / \mathrm{cm}^{3}$. In contrast, incorporating the AP into the foamed slurries engendered a different outcome. In fact, $1 \mathrm{wt} \%$ FA-foamed slurry density tended to decline when the AP content was between 2 and $5 \mathrm{wt} \%$, but beyond this, it was increased by adding more AP, suggesting that incorporating an excessive amount of AP degraded the efficacy of FA. In other words, the amount of AP $\geq 10 \mathrm{wt} \%$ impaired its compatibility with FA. The density-AP content relation curve for the $2 \mathrm{wt} \%$ FA-foamed slurries revealed that an increase in AP content aggressively enhanced the slurry's density from a very low value of $0.69 \mathrm{~g} / \mathrm{cm}^{3}$ for 0 wt $\%$ AP to $1.45 \mathrm{~g} / \mathrm{cm}^{3}$ for $15 \mathrm{wt} \%$ AP. Since the desirable slurry's density is $\leq 1.3 \mathrm{~g} / \mathrm{cm}^{3}$, the upper limit in AP content was set at $5 \mathrm{wt} \%$.

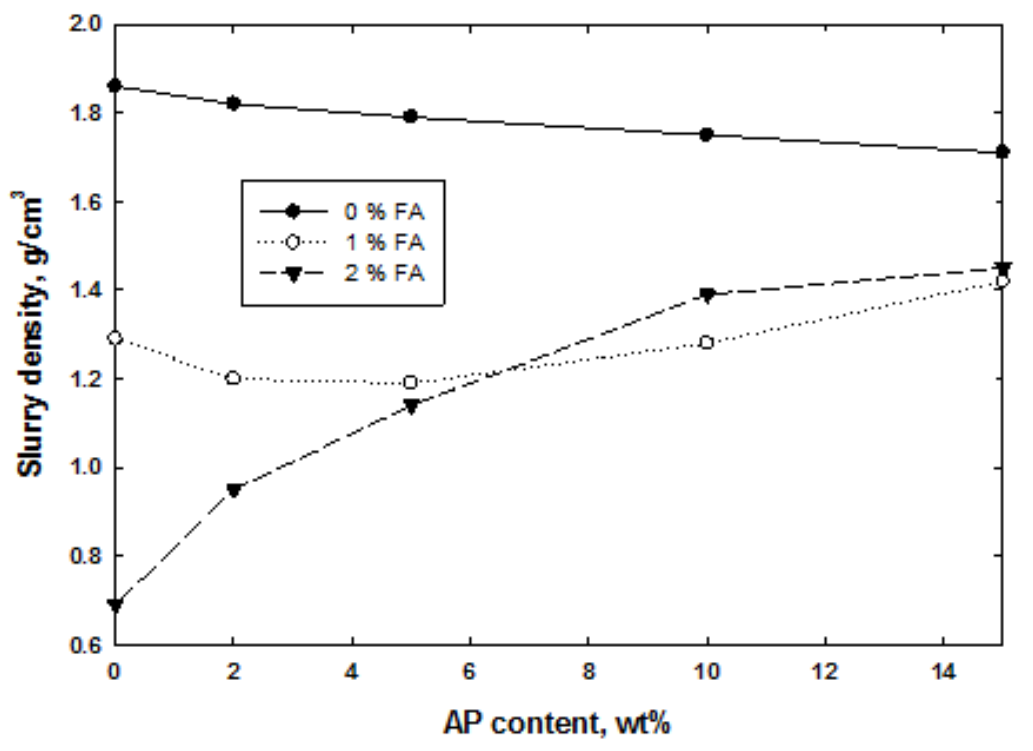

Figure 1. Changes in slurry density for FA-foamed and non-foamed cement slurries as a function of AP content. 


\subsection{Hydrothermal stability of AP in cement}

One inevitable question that must be asked was the susceptibility of AP formed in the cement to the hydrothermal degradation at $200^{\circ} \mathrm{C}$. To answer this question, we prepared the samples consisting of $50 \mathrm{wt} \%$ acrylic emulsion (AE) and $50 \mathrm{wt} \%$ \#80/Class F fly ash/sodium silicate blend cement at room temperature, and then autoclaved them for 24 hours at $85^{\circ}$ and $200^{\circ} \mathrm{C}$, respectively, to conduct FT-IR and TGA analyses. For comparison, AP solid film was made by heating the $\mathrm{AE}$ in an air oven at $85^{\circ} \mathrm{C}$ for 24 hours.

Figure 2 shows the FT-IR spectra over frequency range from 1700 to $1300 \mathrm{~cm}^{-1}$, for bulk AP film as the control, and the APs formed in $85^{\circ} \mathrm{C}$ - and $200^{\circ} \mathrm{C}$-autoclaved cements. The spectral features of the latter two autoclaved samples were characterized by the appearance of two new additional bands, at 1560 and $1409 \mathrm{~cm}^{-1}$, compared with that of the control. The former band was associated with the symmetric stretching of the carboxylate anion, $-\mathrm{COO}^{-}$groups in $-\mathrm{COO}^{-}$ ${ }^{+}$Metal (M) linkage structure, while the latter one reflected anti-symmetric stretching in the same linkage structure.

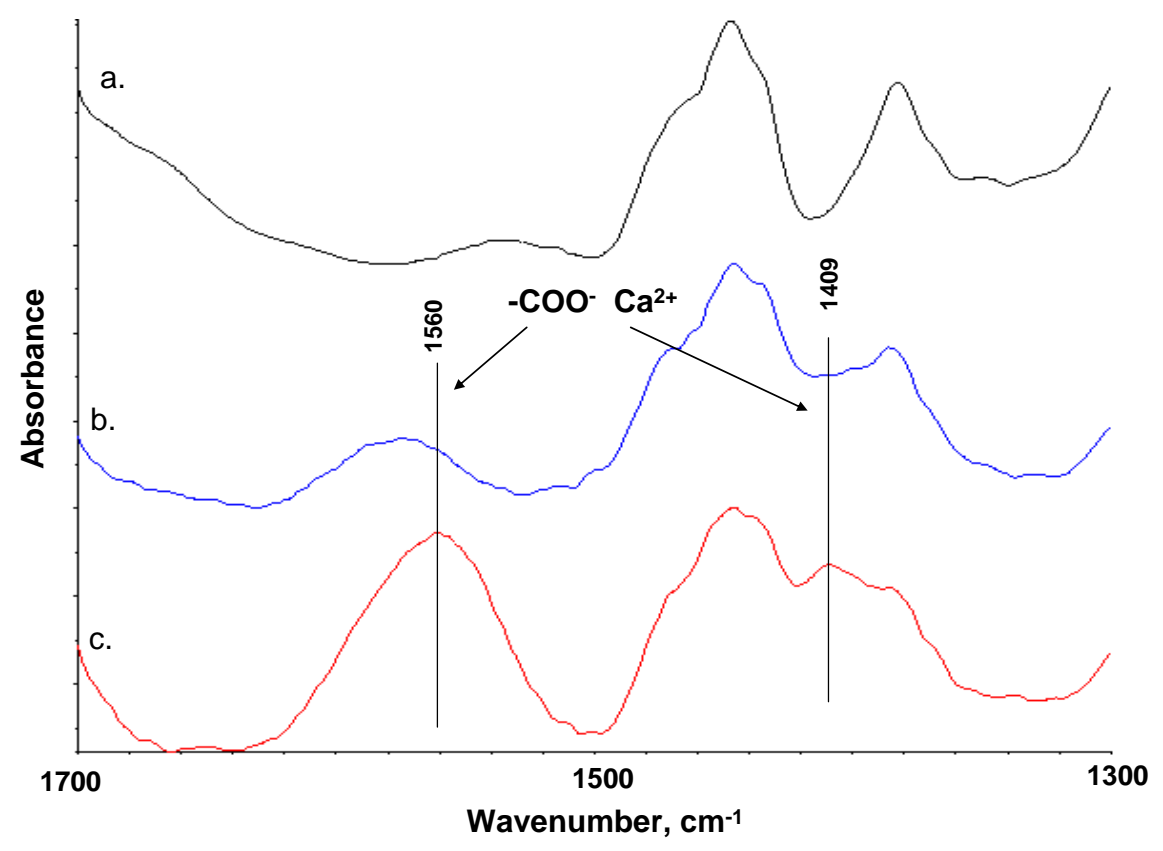

Figure 2. Comparison of FT-IR spectral features for AP film made by heating at $85^{\circ} \mathrm{C}$ (a), and AP formed in cement after autoclaving at $85^{\circ} \mathrm{C}$ (b) and at $200^{\circ} \mathrm{C} \mathrm{(c)}$.

Since $\mathrm{M}$ belonged to the alkali metals and alkaline earth metals, a possible interpretation for the formation of carboxylate anion in autoclaved AP-containing cement is as follows: As is well

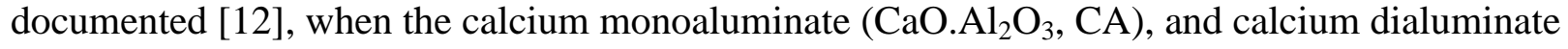


$\left(\mathrm{CaO} .2 \mathrm{Al}_{2} \mathrm{O}_{3}, \mathrm{CA}_{2}\right)$ reactants come in contact with water, three ionic species, $\mathrm{Ca}^{2+}, \mathrm{OH}^{-}$, and $\mathrm{Al}(\mathrm{OH})_{4}{ }^{-}$, are liberated from the surfaces of $\# 80$ cement grains by their hydrolysis. Since the molecular structure of AP contains two functional groups, acrylic acid and alkyl ester (ethyl or butyl ester), these groups preferentially react with hydroxyl-containing hydrolysates precipitated on the \#80 surface in hydrothermal environments at $85^{\circ}$ and $200^{\circ} \mathrm{C}$. This hydrothermal-catalyzed acid-base reaction leads to the in-situ transformation of acrylic acid and alkyl ester into the carboxylate anion derivative, $-\mathrm{COOH}$ or $-\mathrm{COOR}\left(\mathrm{R}, \mathrm{C}_{2} \mathrm{H}_{5}\right.$ or $\left.\mathrm{C}_{4} \mathrm{H}_{9}\right)+\mathrm{OH}^{-} \rightarrow-\mathrm{COO}^{-}+\mathrm{H}_{2} \mathrm{O}$ or $\mathrm{ROH}$. Then, the uptake of $-\mathrm{COO}^{-}$by $\mathrm{Ca}^{2+}$ as its counter cation promotes the assemblage of $\mathrm{Ca}-$ complexed carboxylate structure as the reaction product, $2-\mathrm{COO}^{-}+\mathrm{Ca}^{2+} \rightarrow-\mathrm{COO}^{-} \mathrm{Ca}^{2+} \mathrm{OOC}^{-}$. Also, the other possibility for assembling such a complexed carboxylate structure is the $\mathrm{Na}$ counter cation dissociated from sodium silicate activator, creating the formation of $-\mathrm{COO}^{-} \mathrm{Na}^{+}$ linkage.

As is evident from comparing the spectral features of the $85^{\circ}$ and $200^{\circ} \mathrm{C}$-autoclaved samples, the absorbance of these two new bands appears at $85^{\circ} \mathrm{C}$ but is strikingly enhanced as the hydrothermal temperature rises to $200^{\circ} \mathrm{C}$. Thus, this temperature seemingly promotes the formation of $\mathrm{Ca}$ or $\mathrm{Na}$-complexed carboxylate structure within the AP.

One important material criterion in using AP as a high-temperature corrosion inhibitor is its hydrothermal stability at $\geq 200^{\circ} \mathrm{C}$. Hence, our attention next focused on surveying the thermal stability of AP after $85^{\circ}$ and $200^{\circ} \mathrm{C}$ hydrothermal curing by TGA. The same samples as those used in the previous FT-IR analysis were employed after drying them for 24 hours at $85^{\circ} \mathrm{C}$ to eliminate any free moisture. Figure 3 depicts the TGA curves between $25^{\circ} \mathrm{C}$ and nearly $800^{\circ} \mathrm{C}$ for the $85^{\circ}$ - and $200^{\circ} \mathrm{C}$-autoclaved samples. The thermal decomposition of AP formed in $85^{\circ} \mathrm{C}$ autoclaved samples occurred around $334^{\circ} \mathrm{C}$, while the AP in $200^{\circ} \mathrm{C}$-autoclaved one displayed the thermal decomposition at $\sim 360^{\circ} \mathrm{C}$, which was $\sim 26^{\circ} \mathrm{C}$ higher. The TGA curve of the AP film made by heating at $85^{\circ} \mathrm{C}$ (not shown) was similar to that of $85^{\circ} \mathrm{C}$-autoclaved sample. 


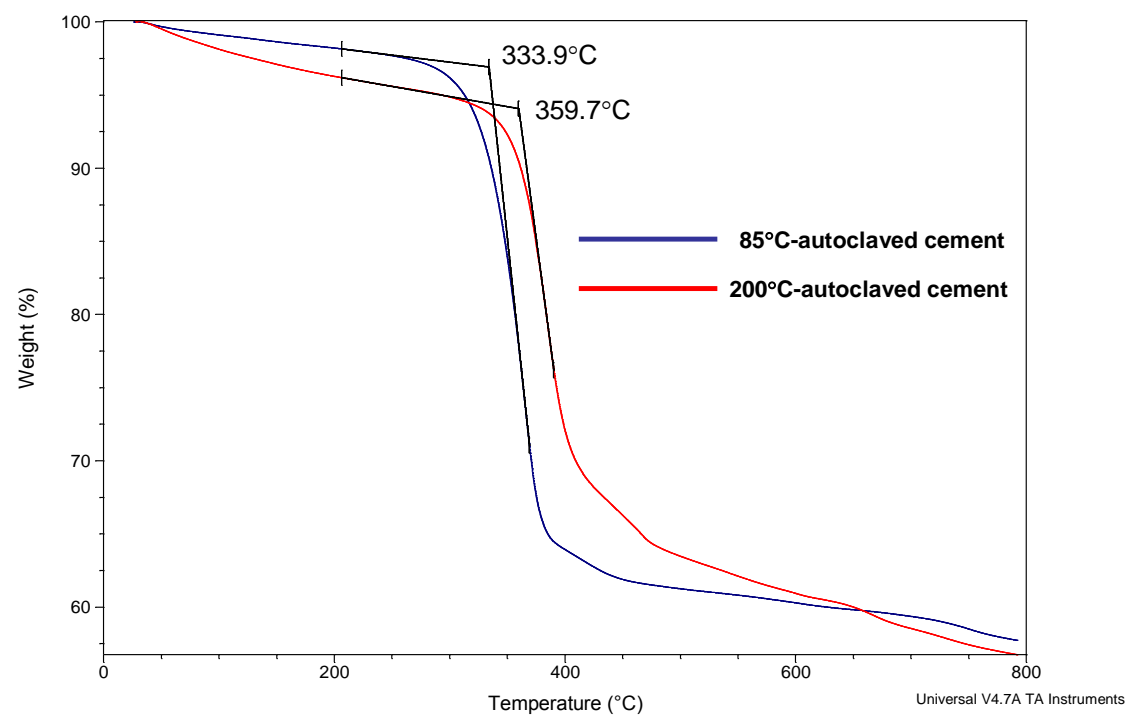

Figure 3. Thermal decompositions of AP formed in $85^{\circ}$ and $200^{\circ} \mathrm{C}$-autoclaved cements.

Combined results of FT-IR and TGA studies highlighted that the hydrothermal stability of AP in autoclaved cement was improved at $200^{\circ} \mathrm{C}$ compared with that at $85^{\circ} \mathrm{C}$. by increased number of M-complexed carboxylate groups in it. , Thus, the AP in cement withstood the $200^{\circ} \mathrm{C}$ hydrothermal temperature.

\subsection{Hydrolysis-hydration reactions of AP-modified foamed cement slurry}

We investigated the effect of FA and AP on cement hydration at $85^{\circ} \mathrm{C}$ in calorimetric tests. Figure 4 depicts the heat flow as a function of elapsed time for non-foamed and foamed cement slurries without AP. For all the samples, the first heat peak attributed to the dissolution of the sodium silicate activator was observed shortly after placing an ampoule with the sample in a calorimeter; the maximum heat flow (MHF) at the peak denoted as No. 1 was reached within 50 min. Afterward, two other 


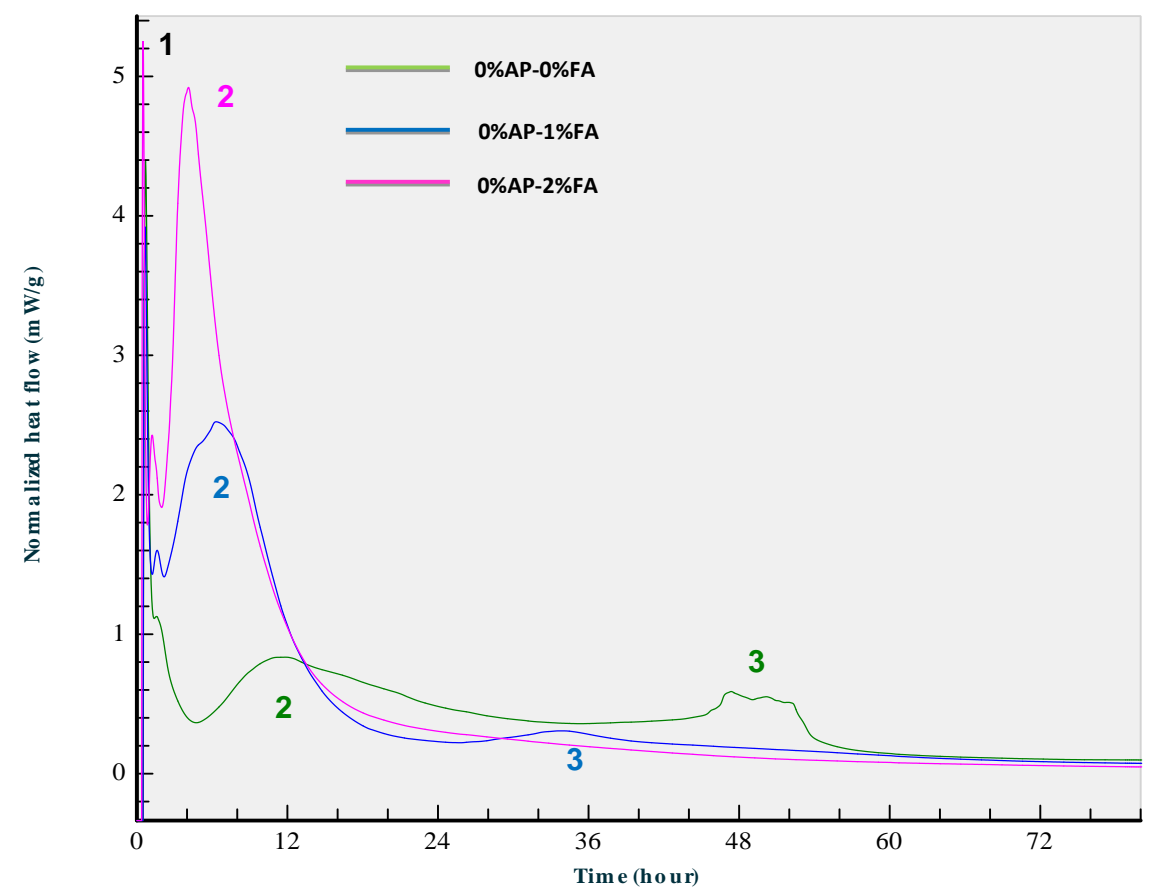

Figure 4. Microcalorimetric curves for non-foamed, and 1 and $2 \mathrm{wt} \%$ FA-foamed cement slurries at isothermal temperature of $85^{\circ} \mathrm{C}$.

heat peaks marked as No. 2 and No. 3 showed for both the non-foamed and $1 \mathrm{wt} \%$ FA-foamed slurries. This cement system consisted of two cement-forming reactants, \#80 and Class F fly ash, our preliminary study (not shown) demonstrated that the hydrolysis-hydration reactions of \#80 were much faster than those of sodium silicate-activated Class F fly ash. Thus, in the nonfoamed cement slurry denoted as $0 \%$ AP-0\%FA, the No. 2 peak emerged at elapsed time of $11 \mathrm{hr}$ 32 min was more likely to be associated with \# 80 reactant than with Class F fly ash; it had MHF of $0.83 \mathrm{~mW} / \mathrm{g}$. The Class F fly ash-related No. 3 peak generated a $0.56 \mathrm{~mW} / \mathrm{g} \mathrm{MHF}$ at the elapsed time of $47 \mathrm{hr} 13 \mathrm{~min}$. When non-foamed slurry was modified with $1 \mathrm{wt} \% \mathrm{FA}$, there were three major differences in comparison with the non-foamed one: First, the length of time to reach No. 2 and No. 3 peaks was shorter; second, the MHF value at the No. 2 peak had risen pronouncedly to $2.52 \mathrm{~mW} / \mathrm{g}$; and, third, the MHF value at No. 3 peak had declined by $\sim 45 \%$ to $0.31 \mathrm{~mW} / \mathrm{g}$. These results seemingly suggested that the foaming agent preferentially promoted the hydrolysis-hydration reactions of \#80, rather than that of Class F fly ash. In fact, adding more foaming agent at $2 \mathrm{wt} \%$ further promoted \#80's reactions, showing $48 \%$ increase of MHF to $4.88 \mathrm{~mW} / \mathrm{g}$, compared with that at $1 \mathrm{wt} \%$.

Table 1 lists the elapsed times at the onset and end of No. 2 and No. 3 peaks along with the heat evolved during these reactions for non-foamed and foamed-cement slurries at $85^{\circ} \mathrm{C}$. The heat was computed from the area enclosed by the heat flow-elapsed time curve with the baseline extending between its beginning and the end. The No.2 peak, attributed to \#80's hydrolysishydration reactions, clearly verified that FA accelerated the onset of this reaction; namely, compared with $4 \mathrm{hr} 6 \mathrm{~min}$ for FA-free slurry, the reaction onset was shortened to $1 \mathrm{hr} 59 \mathrm{~min}$ by increasing FA content to $1 \mathrm{wt} \% \mathrm{FA}$, and to $1 \mathrm{hr} 43 \mathrm{~min}$ for $2 \mathrm{wt} \% \mathrm{FA}$. The evolved heat also increased with an increasing FA content; in fact, a $50.1 \mathrm{~J} / \mathrm{g}$ generated at $2 \mathrm{wt} \%$ FA was $51 \%$ 
higher than heat evolved from non-foamed slurry. However, as for the Class F fly ash-related heat, the value of $11.8 \mathrm{~J} / \mathrm{g}$ for non-foamed slurry declined 1.8 times when $1 \mathrm{wt} \% \mathrm{FA}$ was added to it. Nevertheless, the total heating energies evolved from No. 2 and No. 3 peaks rose with an increasing FA content, although there was no visual evidence of No. 3 peak for 2 wt $\%$ FA.

Table 1. Summarized microcalorimetric test results for non-foamed, and 1 and $2 \mathrm{wt} \%$ FAfoamed cement slurries at $85^{\circ} \mathrm{C}$

\begin{tabular}{|c|c|c|c|c|c|c|c|}
\hline \multirow[t]{2}{*}{$\overline{F A}, \mathrm{wt} \%$} & \multicolumn{3}{|c|}{ No. 2 peak } & \multicolumn{3}{|c|}{ No. 3 peak } & \multirow{2}{*}{$\begin{array}{l}\text { Total } \\
\text { evolved } \\
\text { heat, } \mathrm{J} / \mathrm{g}\end{array}$} \\
\hline & $\begin{array}{l}\text { Onset } \\
\text { time, } \\
\mathrm{hr}: \text { min }\end{array}$ & $\begin{array}{l}\text { End time, } \\
\text { hr : min }\end{array}$ & $\begin{array}{l}\text { Evolved } \\
\text { heat, J/g }\end{array}$ & $\begin{array}{l}\text { Onset } \\
\text { time, } \\
\mathrm{hr}: \text { min }\end{array}$ & $\begin{array}{l}\text { End time, } \\
\mathrm{hr}: \mathrm{min}\end{array}$ & $\begin{array}{l}\text { Evolved } \\
\text { heat, J/g }\end{array}$ & \\
\hline 0 & $4: 06$ & $34: 28$ & 24.5 & $33: 53$ & $60: 41$ & 11.8 & 36.3 \\
\hline 1 & $1: 59$ & $22: 19$ & 33.9 & $25: 06$ & $48: 02$ & 6.5 & 40.4 \\
\hline 2 & $1: 43$ & $18: 07$ & 50.1 & - & - & - & 50.1 \\
\hline
\end{tabular}

Figure 5 depicts heat flow-elapsed time curves for $2 \mathrm{wt} \%$ FA-foamed cement slurries modified with $2,5,10$, and $15 \mathrm{wt} \% \mathrm{AP}$ at $85^{\circ} \mathrm{C}$. Addition of AP changed the curves in two major ways: One was the appearance of Class F fly ash-related No.3 peak at elapsed time of $34 \mathrm{hr} 5 \mathrm{~min}$; the other was some extension of elapsed time to reach \#80-related No.2 peak from $3 \mathrm{hr} 56 \mathrm{~min}$ for $0 \mathrm{wt} \%$ AP slurry to $11 \mathrm{hr} 42 \mathrm{~min}$ for $2 \mathrm{wt} \%$ AP, while No.1 peak representing the heat flow due to the dissolution of sodium silicate had emerged within $\sim 30$ min after placing the slurry sample in a calorimeter.

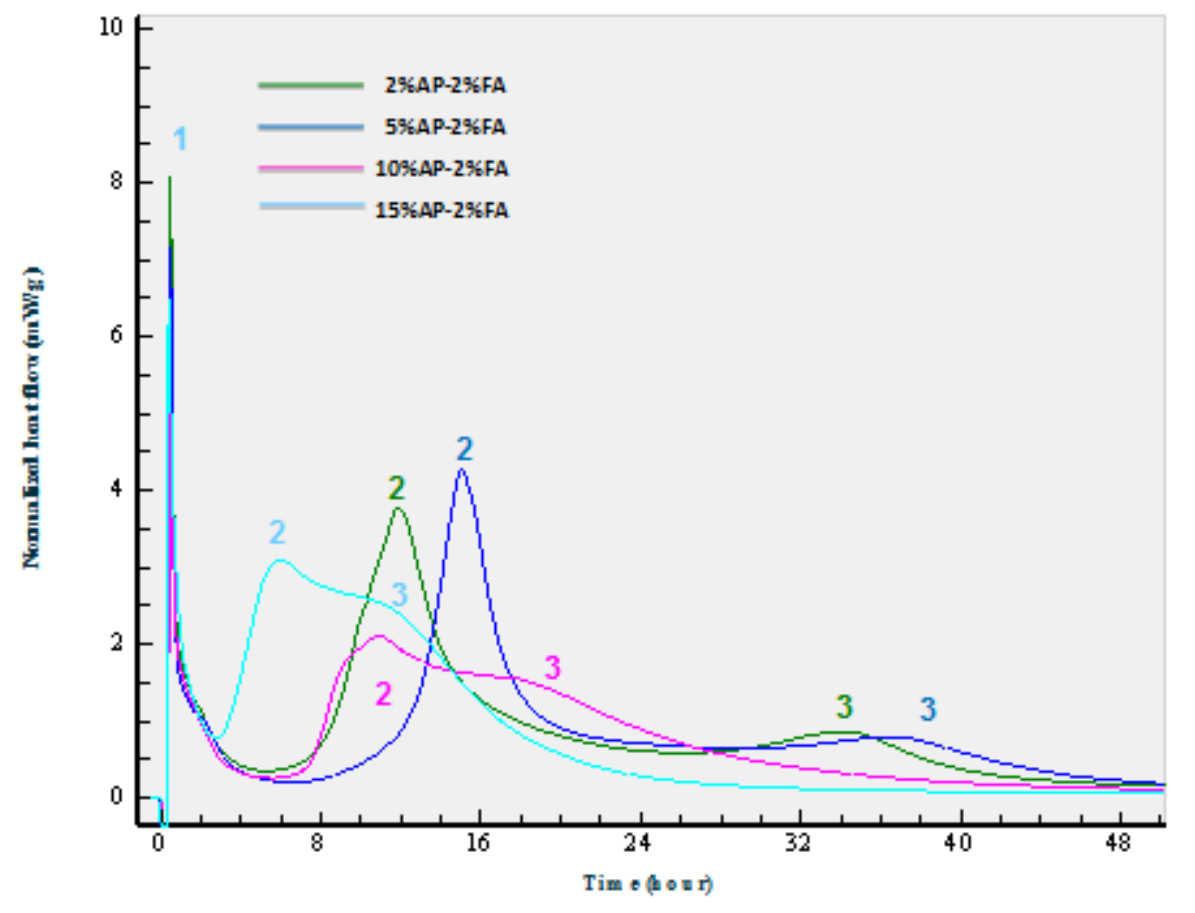

Figure 5. Heat flow-time reaction curves for $2 \mathrm{wt} \%$ FA-foamed slurries modified with 2, 5, 10, and $15 \mathrm{wt} \% \mathrm{AP}$. 
The values of MHF were 8.08, 3.74, and $0.86 \mathrm{~mW} / \mathrm{g}$ at No.1, 2, and 3 peaks, respectively. Increasing the AP content to $5 \mathrm{wt} \%$ further delayed the time at which the No.2 and No.3 peaks were reached, to $14 \mathrm{hr} 57 \mathrm{~min}$ and $36 \mathrm{hr} 48 \mathrm{~min}$. However, the values of their MHF at No. 2 and No.3 peaks were almost the same as those of $2 \mathrm{wt} \%$ AP, seemingly suggesting that AP retarded the hydrolysis-hydration reaction of both the \#80 and Class F fly ash reactants, but it did not affect significantly their magnitude. Interestingly, incorporating more AP into the slurry accelerated these reactions. In fact, by adding $10 \mathrm{wt} \%$ AP, the elapsed times before the appearance of both the No. 2 and No. 3 peaks were markedly shorter than for the $5 \mathrm{wt} \%$ AP. A more pronounced shift of these peaks was observed at $15 \mathrm{wt} \%$ AP. Also, incorporating more AP resulted in the transformation of the two separated peaks, No.2 and No.3 observed at 2 and 5 wt $\%$ AP into a united doublet peak at 10 and $15 \mathrm{wt} \%$ AP.

Table 2 summarizes the elapsed times at onset and end of each No. 2 and No. 3 peaks in conjunction with the total energy evolved from these reactions for 0,2 , and $5 \mathrm{wt} \%$ AP-modified foamed slurries. As is evident from these data, AP content in the range of 2-5 wt $\%$ retard the \#80 reaction; the onset time of this reaction for unmodified foamed slurry was delayed by as much as 4 and 5 hours at 2 and $5 \mathrm{wt} \%$ of AP, respectively. On the other hand, the total energy evolved from the No. 2 and No. 3 reactions was enhanced with an increasing content of AP, from $50.1 \mathrm{~J} / \mathrm{g}$ for $0 \mathrm{wt} \%$ to $74.4 \mathrm{~J} / \mathrm{g}$ for $5 \mathrm{wt} \%$, implying that AP extended the hydrolysis-hydration reactions of both \#80 and Class F fly ash. Although there was no experimental evidence, we deemed that such enhancement of reaction energy by adding AP may be associated with the energy generated by the acid-base interactions between the AP and $\mathrm{Ca}^{2+}$ or $\mathrm{Na}^{+}$liberated from $\# 80$ and sodium silicate to form $\mathrm{Ca}$ - or $\mathrm{Na}$-complexed carboxylate structure as the reaction products.

Table 2. Summarized No. 2 and 3 reaction behaviors for 2 and 5 wt \% AP-modified and unmodified foamed slurries

\begin{tabular}{|c|c|c|c|c|c|c|c|}
\hline \multirow[t]{2}{*}{ AP, wt $\%$} & \multicolumn{3}{|c|}{ No. 2 reaction } & \multicolumn{3}{|c|}{ No. 3 reaction } & \multirow{2}{*}{\begin{tabular}{|l|} 
Total \\
evolved \\
heat, $\mathrm{J} / \mathrm{q}$
\end{tabular}} \\
\hline & $\begin{array}{l}\text { Onset } \\
\text { time, } \\
\mathrm{hr}: \text { min }\end{array}$ & $\begin{array}{l}\text { End time, } \\
\mathrm{hr}: \min \end{array}$ & $\begin{array}{l}\text { Evolved } \\
\text { heat, J/g }\end{array}$ & $\begin{array}{l}\text { Onset } \\
\text { time, } \\
\mathrm{hr}: \min \end{array}$ & $\begin{array}{l}\text { End time, } \\
\mathrm{hr}: \min \end{array}$ & $\begin{array}{l}\text { Evolved } \\
\text { heat, J/g }\end{array}$ & \\
\hline 0 & $1: 43$ & $18: 07$ & 50.1 & - & - & - & 50.1 \\
\hline 2 & $5: 33$ & $21: 51$ & 55.8 & $26: 03$ & $45: 35$ & 10.8 & 66.6 \\
\hline 5 & $6: 49$ & $22: 14$ & 61.6 & $27: 35$ & $50: 45$ & 12.8 & 74.4 \\
\hline
\end{tabular}

Since the heat flow-elapsed time curves for 10 and $15 \mathrm{wt} \%$ AP revealed merged peaks from No. 2 and No. 3 reactions. Accordingly, the onset and the end of these combined reactions were determined at the beginning of No. 2 peak and at the end of No. 3 peak (Table 3). As described earlier, an excessive amount of AP accelerated No. 2 reaction. The onset of the reaction was shortened by adding $10 \mathrm{wt} \%$ AP to $5 \mathrm{hr} 8 \mathrm{~min}$ from $6 \mathrm{hr} 49$ min with $5 \mathrm{wt} \%$ AP. A further acceleration to $2 \mathrm{hr} 18 \mathrm{~min}$ was observed at $15 \mathrm{wt} \%$ AP. If our hypothesis is valid, the acid-base interactions between AP, and \#80 and sodium silicate promote the extent of hydrolysis-hydration reactions of \#80 and Class F fly ash generating more heat. Correspondingly, at 10 and $20 \mathrm{wt} \%$ AP, the total evolved energy was 92.0 and $87.4 \mathrm{~J} / \mathrm{g}$, respectively, reflecting $\sim 23$ and $\sim 18 \%$ increase in comparison with 5 wt $\%$ AP slurry. 
Table 3. Onset and end times of the hydrolysis-hydration reactions along with the total evolved heat for 10 and $15 \mathrm{wt} \%$ AP-modified slurries

\begin{tabular}{|l|l|l|l|}
\hline \multirow{2}{*}{ AP, wt\% } & \multicolumn{2}{|l|}{ No.2 and 3 peaks } & $\begin{array}{l}\text { Total evolved heat } \\
\text { energy, J/g }\end{array}$ \\
\cline { 2 - 4 } & $\begin{array}{l}\text { Onset time, } \\
\text { hr }: \text { min }\end{array}$ & $\begin{array}{l}\text { End time, } \\
\text { hr }: \text { min }\end{array}$ & 92.0 \\
\hline 10 & $5: 08$ & $40: 48$ & 87.4 \\
\hline 15 & $2: 18$ & $32: 23$ & \\
\hline
\end{tabular}

We expected that increased reactions heat should improve mechanical strength of the material and next assessed the effect of AP on the compressive-strength and-toughness of autoclaved foamed cements.

\subsection{Compressive-strength and -toughness}

Figure 6 plots the compressive strength of the $200^{\circ} \mathrm{C}$-autoclaved foamed and non-foamed cements modified with $0,2,5,10$, and $15 \mathrm{wt} \%$ AP. The value of compressive strength for both the foamed and non-foamed cements depended on the content of AP; their strength rose with an increasing AP content. Even with only $2 \mathrm{wt} \%$, the strength of non-foamed cements, denoted as 0 $\%$ FA, improved by $35 \%$ to $9.5 \mathrm{MPa}$. A similar improvement was observed from 1 and $2 \mathrm{wt} \%$ FA-foamed cements. Increasing the AP content to $15 \mathrm{wt} \%$ considerably strengthened these cements; in fact, the compressive strength of of 18.6, 15.8, and 13.9 MPa developed in the nonfoamed, and 1 and $2 \mathrm{wt} \%$ FA-foamed cements, respectively, were equivalent to 2.6-, 3.4-, and 24.4-fold improvements compared with that of AP-free cements.

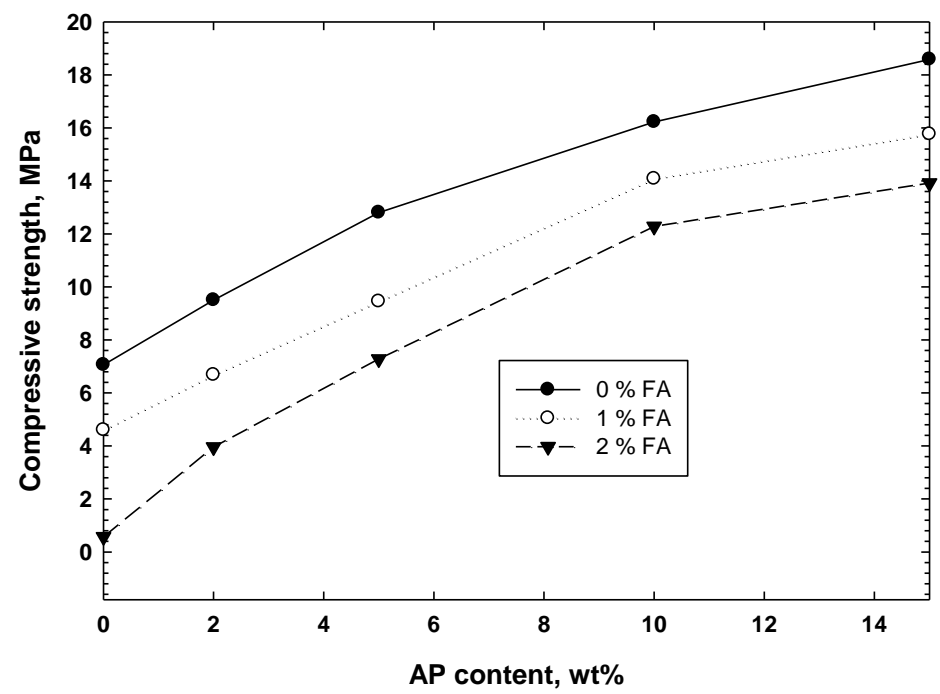

Figure 6. Changes in compressive strength of the $200^{\circ} \mathrm{C}$-autoclaved foamed and non-foamed cements as a function of AP content. 
To obtain quantitative data on the ductility of these cements, we determined the compressive toughness, $\mathrm{J} / \mathrm{mm}^{3}$, as the total energy consumed until compressive force caused the cement to fail; this value was computed from the enclosed area of the compressive stress-strain curve with the baseline extending between the beginning and the end of this curve. Figure 7 plots the compressive toughness verses AP content for non-foamed, 1, and $2 \mathrm{wt} \%$ FA-foamed cements containing $2,5,10$, and $15 \mathrm{wt} \% \mathrm{AP}$ after autoclaving at $200^{\circ} \mathrm{C}$. For all these samples, the toughness-AP content relation curves revealed that their toughness progressively rose with the first $5 \mathrm{wt} \%$ content of AP, beyond that, it increased more gradually with an increasing AP content up to $15 \mathrm{wt} \%$. At $5 \mathrm{wt} \% \mathrm{AP}$, the recorded values of $0.55,0.49$, and $0.38 \mathrm{~J} / \mathrm{mm}^{3} \times 10^{3}$ toughness for non-foamed, 1 and $2 \mathrm{wt} \%$ FA-foamed cements, respectively, corresponded to nearly 3.2-, 3.5, and 5.4-fold improvements from that of AP-free cements.

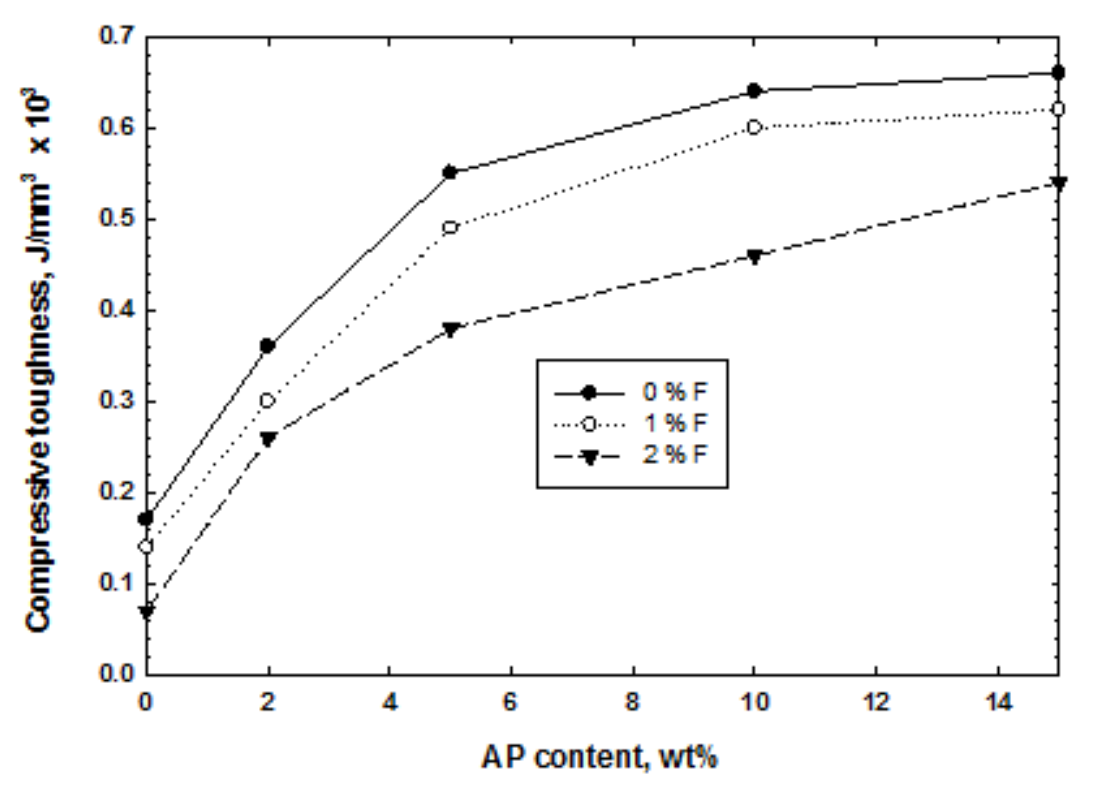

Figure 7. Compressive toughness versus AP content for $200^{\circ} \mathrm{C}$-autoclaved foamed and nonfoamed cements.

Thus, AP additive offered a great improvement of cement's compressive-strength and-toughness in a hydrothermal environment at $200^{\circ} \mathrm{C}$, supporting our assumption that the increased total evolved reaction heat in the presence of AP assures advanced mechanical properties of foamed cement.

\subsection{Phase identification and microstructure development}

One intriguing question of the incorporation of AP into the cement was whether it would change the composition of the crystalline phases with the hydrothermal reaction products responsible for strengthening the autoclaved foamed cement. To obtain this information, XRD was used to identify the phases in the $2 \mathrm{wt} \%$ FA-foamed cements containing $0,5,10$, and $15 \mathrm{wt} \% \mathrm{AP}$ after autoclaving at $200^{\circ} \mathrm{C}$. Figure 8 depicts the XRD traces for these powder samples. For AP-free foamed cement, the XRD pattern (a) showed that the cement was composed of the four crystalline hydration reaction products, hydroxysodalite $\left[\mathrm{Na}_{4} \mathrm{Al}_{3} \mathrm{Si}_{3} \mathrm{O}_{12}(\mathrm{OH})\right]$, boehmite $(\gamma$ - 
$\mathrm{AlOOH})$, Si-free katoite $\left[\mathrm{Ca}_{5} \mathrm{Al}_{2}(\mathrm{OH})_{12}\right]$, and intermediate hydrogrossular $\left[\mathrm{Ca}_{3} \mathrm{Al}_{2} \mathrm{Si}_{2} \mathrm{O}_{8}(\mathrm{OH})_{4}\right]$ phases, and the four non-reacted crystalline products, mullite $\left(3 \mathrm{Al}_{2} \mathrm{O}_{3} .2 \mathrm{SiO} 2\right)$, quartz $\left(\mathrm{SiO}_{2}\right)$, corundum $\left(\alpha-\mathrm{Al}_{2} \mathrm{O}_{3}\right)$, and hematite $\left(\mathrm{Fe}_{2} \mathrm{O}_{3}\right)$, attributed to the $\# 80$ and Class $\mathrm{F}$ fly ash as the starting cement-forming materials. The hydroxysodalite and hydrogrossular phases were formed by hydrothermal interactions between the sodium silicate activator and Class F fly ash, while the hydration reaction of \#80 led to the formation of two other phases, boehmite and Si-free katoite. When this cement was modified with 5 to $15 \mathrm{wt} \%$ AP, these XRD patterns closely resembled that of AP-free one, except for the appearance of non-reacted sodium silicate-related $d$-spacing line. Further, this line was intensified with an increasing AP content, suggesting that adding more AP impaired the reactivity of sodium silicate. Otherwise, the AP had no effect upon the final phase composition of the $200^{\circ} \mathrm{C}$-autoclaved foamed cement.

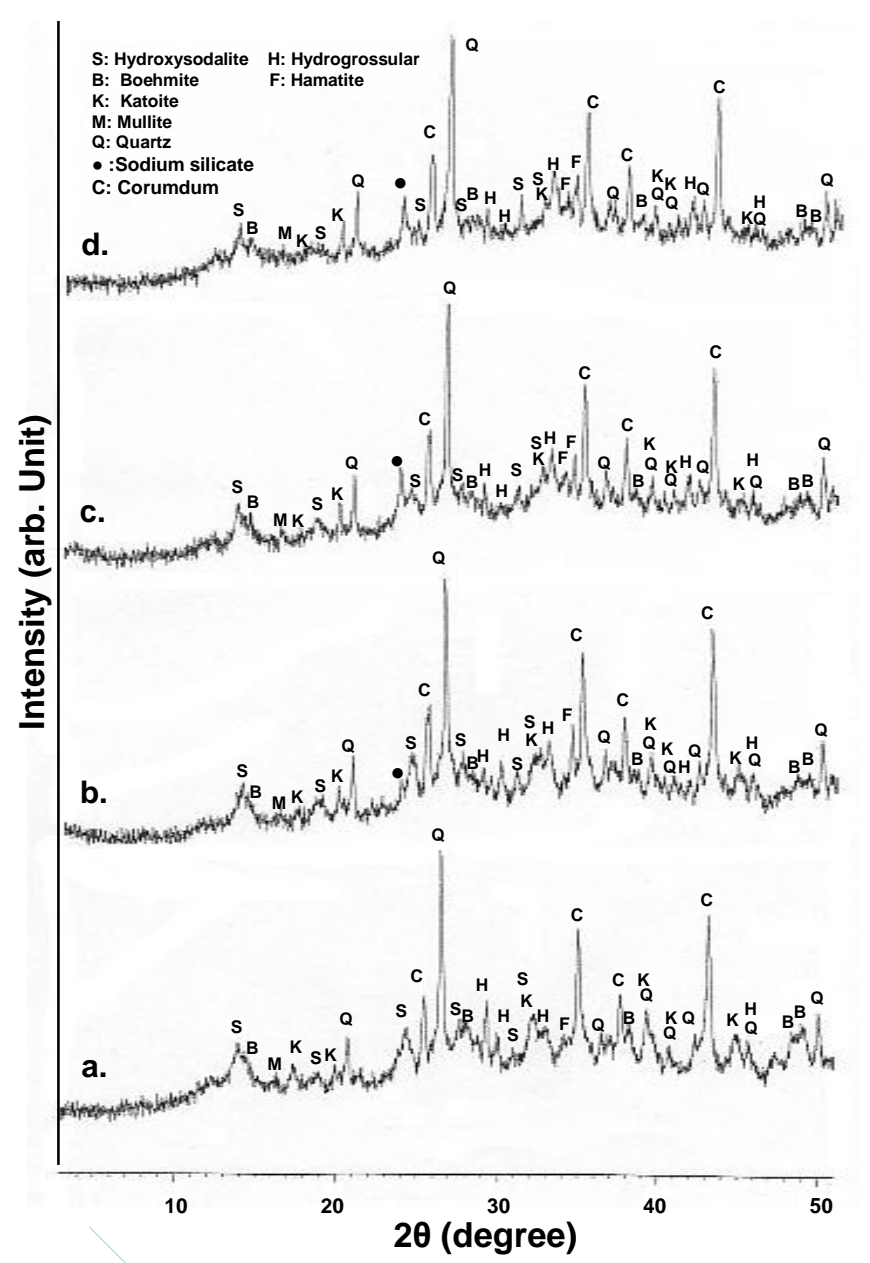

Figure 8. XRD tracing of $200^{\circ} \mathrm{C}$-autoclaved $2 \mathrm{wt} \%$ FA-foamed cements containing (a) 0, (b) 5 , (c) 10 , and (d) $15 \mathrm{wt} \% \mathrm{AP}$.

Our attention next shifted to exploring the microstructure developed in the foamed cement in the presence of AP. Figure 9 shows the SEM images for the fractured surfaces of AP-free nonfoamed cement as the control, and $2 \mathrm{wt} \%$ FA-foamed cements with and without AP. Compared 
with the microstructure of the control, adding the FA to it engendered a striking alteration; the transformation of the dense morphology for non-foamed cement into the porous morphology for foamed one. The image of the $2 \mathrm{wt} \% \mathrm{FA}$-foamed cement made by incorporating numerous air bubbles into slurry revealed a typical honeycomb-like porous structure encompassing craters of $\sim 300$ to $\sim 50 \mu \mathrm{m}$. Most of these craters had a partially defective structure, which can be interpreted as
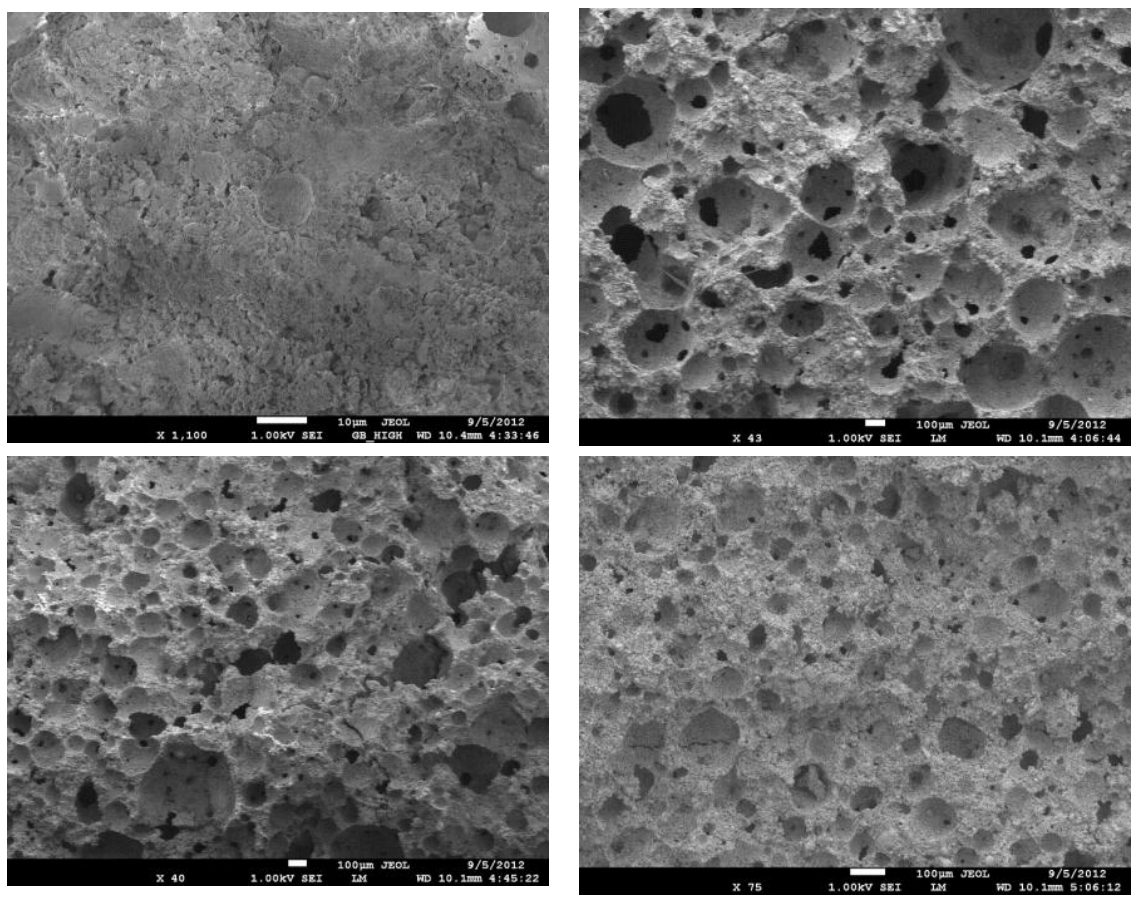

Figure 9. SEM images for fractured surfaces of non-foamed cement (top left), $2 \mathrm{wt} \%$ FA-foamed cement (top right), and 2 wt $\%$ FA-foamed cements modified with 2 wt\% AP (bottom left) and 10 wt\% AP (bottom right).

the formation of continuous voids. After modifying it with $2 \mathrm{wt} \%$ AP, the image represented creators of much smaller-size, compared with that of unmodified foamed cement. Additionally, the defects in individual creators were minimal, implying that AP aided the formation of discrete voids. This finding was strongly supported by the image of $10 \mathrm{wt} \% \mathrm{AP}$-modified foamed cement; increasing the AP content resulted in more defect-free craters. Unlike the continuous void-constituted porous structure in the foamed cement, we can assume that the structure assembled by discrete voids would reduce the rates of permeability and transportation of corrosive electrolytes through the cement, assuring the cement's ability to protect carbon steel (CS) against corrosion.

\subsection{Corrosion mitigation}

To verify the potential of AP to mitigate the corrosion of CS, we conducted two electrochemical corrosion studies: The first centered on investigating the resistance of AP to the infiltration and transportation of corrosive electrolyte through the foamed cement layer covering the underlying 
CS surfaces; and, the second one was the survey of the effect of AP in preventing the corrosion of CS at the interfaces between the metal and the foamed cement. The latter study also involved evaluation of the extent of the CS surface coverage by cement, the cathodic corrosion protection along with the corrosion rates of CS. Another important factor investigated in corrosion protection was the adherence of coating to CS [13].

\subsubsection{EIS test}

One major parameter governing the mitigation of corrosion by the cements is their conductivity of corrosive electrolytes; the extent of electrolytes uptake by the cements plays a pivotal role in inhibiting or accelerating the corrosion of the underlying CS casing. Our approach to obtaining this information was to determine the extent of conductivity and transportation of ionic electrolytes through the cement layer deposed on CS surfaces using EIS. The samples for EIS testing were prepared in the following manner: First, alkaline-cleaned CS coupons were dipped in a bath containing AP-modified or unmodified foamed cement slurry at room temperature; second, the slurry-covered coupons were left for 24 hours at room temperature, allowing the slurry to set; third, the room-temperature-cured cement layer-coated CS were autoclaved for 24 hours at $200^{\circ} \mathrm{C}$; and, finally, the autoclaved cement-covered CS coupon were left at room temperature to cool before EIS testing. Afterward, the coated CS coupons plates were mounted in a holder, and then inserted into a flat electrochemical cell. The coated coupon with a surface area of $13 \mathrm{~cm}^{2}$ was exposed to aerated $1.0 \mathrm{M}$ sodium chloride electrolyte at $25^{\circ} \mathrm{C}$ for $10 \mathrm{~min}$ before the EIS test.

Figure 10 compares the Bode-plot features [the absolute value of impedance $|\mathrm{Z}|\left(\mathrm{ohm}-\mathrm{cm}^{2}\right)$ vs. frequency $(\mathrm{Hz})]$ of the coupons coated with the non-foamed cements modified with $0,5,10$, and $15 \mathrm{wt} \%$ AP. Particular attention in the overall EIS curve was paid to the pore resistance, $R_{p}$, which can be determined from the peak in the Bode-plot occurring at a sufficiently low frequency between $10^{-1}$ and $10^{-2} \mathrm{~Hz}$. For the AP-unmodified cement coating, the $R_{p}$ value was $76.5 \mathrm{ohm}-\mathrm{cm}^{2}$. This value strikingly rose by nearly two times to $138.9 \mathrm{ohm}-\mathrm{cm}^{2}$, when this coating was modified with $5 \mathrm{wt} \%$ AP. Since the $R_{p}$ value reflects the extent of ionic conductivity generated by the $\mathrm{NaCl}$ electrolyte passing through the coating layer, such an increase represented a reduction in the uptake of electrolytes by the coating. In other words, the coating modified with AP had a better resistance to infiltration and transportation of electrolyte through its layer. Incorporating more AP into the coating further increased the $R_{p}$ value to 155.9 and $216.3 \mathrm{ohm}-$ $\mathrm{cm}^{2}$ for 10 and $15 \mathrm{wt} \% \mathrm{AP}$, respectively, strongly demonstrating that the coating's efficacy as corrosion-preventing barrier layer was improved with greater AP content. 


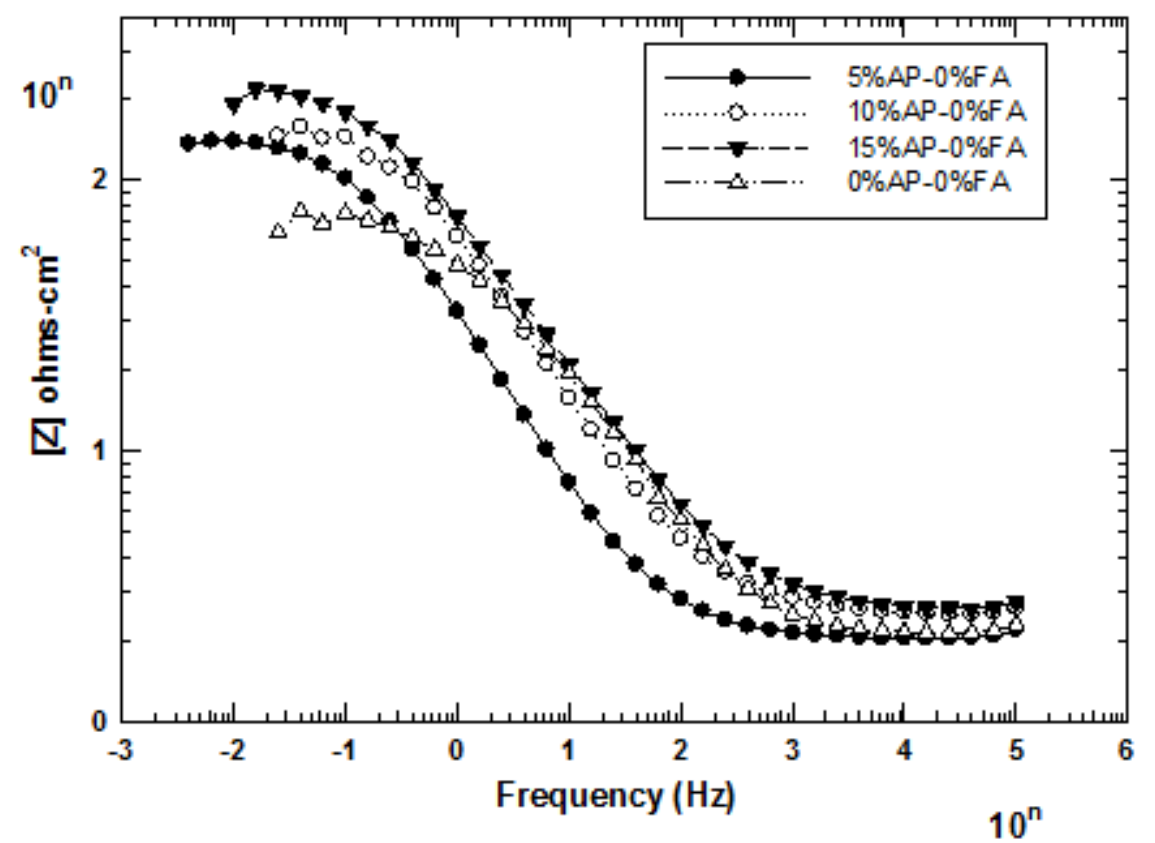

Figure 10. AC electrochemical impedance curves for non-foamed cements modified with 0,5 , 10 , and $15 \mathrm{wt} \% \mathrm{AP}$ after autoclaving at $200^{\circ} \mathrm{C}$.

Figure 11 shows the Bode-plot curves of the coupons coated with $1 \mathrm{wt} \%$ FA-foamed cements containing $0,5,10$, and $15 \mathrm{wt} \% \mathrm{AP}$. The $R_{p}$ value of AP-free foamed cement coating marked as $0 \% \mathrm{AP}-1 \% \mathrm{FA}$ was $51.4 \mathrm{ohm}-\mathrm{cm}^{2}$, corresponding to $33 \%$ lower value than that of AP-free non-foamed cement coating. It appeared that the foamed cement allowed the electrolytes to infiltrate more readily through its coating layer, compared with that of non-foamed one. As expected, adding $5 \mathrm{wt} \%$ AP reduced the electrolyte's uptake by foamed cement coating, leading to the increase in $R_{p}$ value to $78 \mathrm{ohm}-\mathrm{cm}^{2}$. A further lowering of its uptake was observed at 10 and $15 \mathrm{wt} \% \mathrm{AP}$; in fact, the $R_{p}$ values of these coatings were more than $200 \mathrm{ohm}-\mathrm{cm}^{2}$.

Relating these findings to the results from our study of microstructure development, there were two possible mechanisms for minimizing the rate of electrolyte infiltration through the foamed cement by AP: One was creation of porous structure composed of defect-free discrete voids; the other was related to the in-situ formation of an electrolyte-impervious AP film in the foamed cement. 


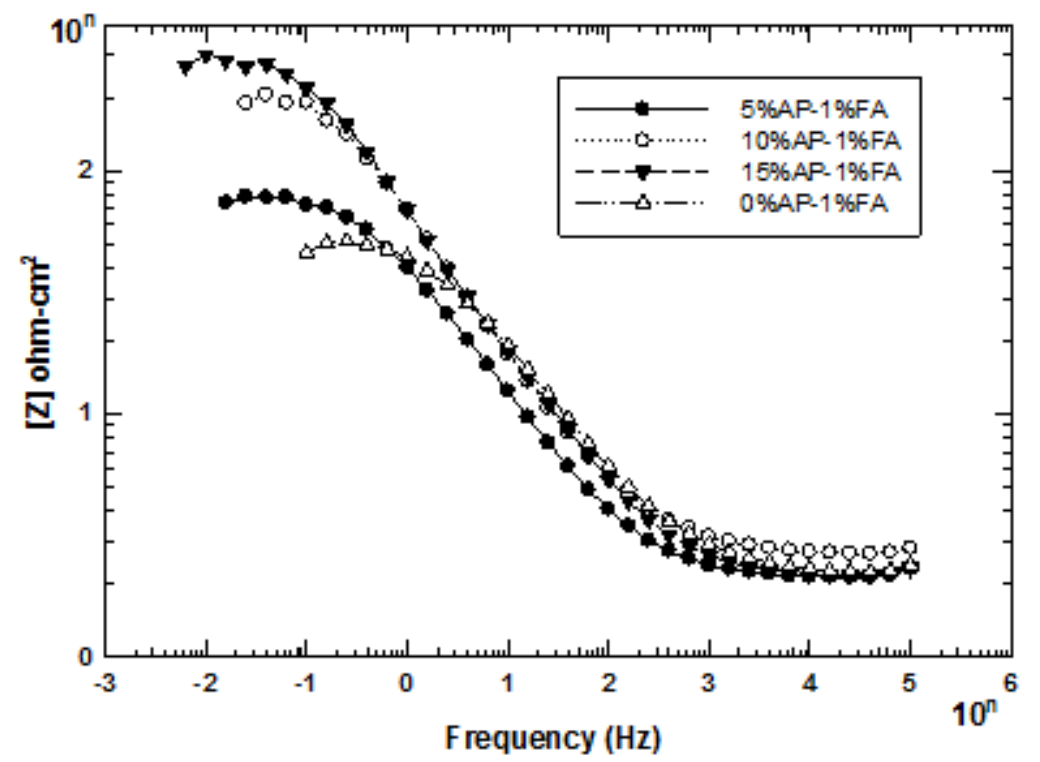

Figure 11. Comparison of EIS curves for $1 \mathrm{wt} \%$ FA-foamed cements modified with 0,5 , 10, and $15 \mathrm{wt} \%$ AP after autoclaving at $200^{\circ} \mathrm{C}$.

\subsubsection{DC potentiodynamic polarization test}

For this test, we prepared the samples in the same manner as those employed in the EIS test. Figure 12 illustrates the typical cathodic-anodic polarization curves of the potential voltage, $E$, versus current density, $\mathrm{A} / \mathrm{cm}^{2}$, for CS coupons covered with the $1 \mathrm{wt} \% \mathrm{FA}$-foamed cements modified with $0,2,5,10$, and $15 \mathrm{wt} \%$ AP. The shapes of the curve reveal the transition from cathodic polarization region at the onset of the most negative potential to the anodic polarization region at the end of a lower negative potential. The potential axis at the transition point from cathodic to anodic is normalized as the corrosion potential, $E_{c o r r}$. Compared with the curve from AP-free foamed cement denoted as $0 \%$ AP-1\% FA, there were two noticeable differences for the CS coated with 2 and $5 \mathrm{wt} \%$ AP-modified cements: One was a shift in the $E_{c o r r}$ value to a positive potential site; the other was the reduction of cathodic current density $\left(\mathrm{A} / \mathrm{cm}^{2}\right)$ between 0.6 and $-0.7 \mathrm{~V}$. The first difference directly reflects the extent of coverage of the cement over the CS surface; namely, a good coverage by a continuous void-free coating layer is responsible for moving the $E_{c o r r}$ value to a positive potential site. Thus, the shift to positive site of $E_{\text {corr }}$ underscored that the extent of coverage by the foamed cements increased with 2 and $5 \mathrm{wt} \%$ AP. For the second difference, the decline in cathodic current density signified that the cathodic reaction at the corrosion site of CS was restrained, particularly the oxygen reduction reaction, $2 \mathrm{H}_{2} \mathrm{O}+\mathrm{O}_{2}+4 \mathrm{e}^{-} \rightarrow 4 \mathrm{OH}^{-}$. Correspondingly, such a reaction leading to the cathodic corrosion of CS appeared to be inhibited by depositing the AP-modified foamed cement on the CS surfaces, 
thereby highlighting the capability of AP to abate the corrosion of CS. A further improvement of these two important corrosion-preventing factors, 1) extending the coverage by cement and 2) inhibiting the cathodic corrosion reaction, was observed from the polarization curves of the 10 and $15 \mathrm{wt} \%$ AP-modified foamed cement coatings. Thus the incorporation of more AP into the foamed cement conferred a better protection of CS against brine-caused corrosion.

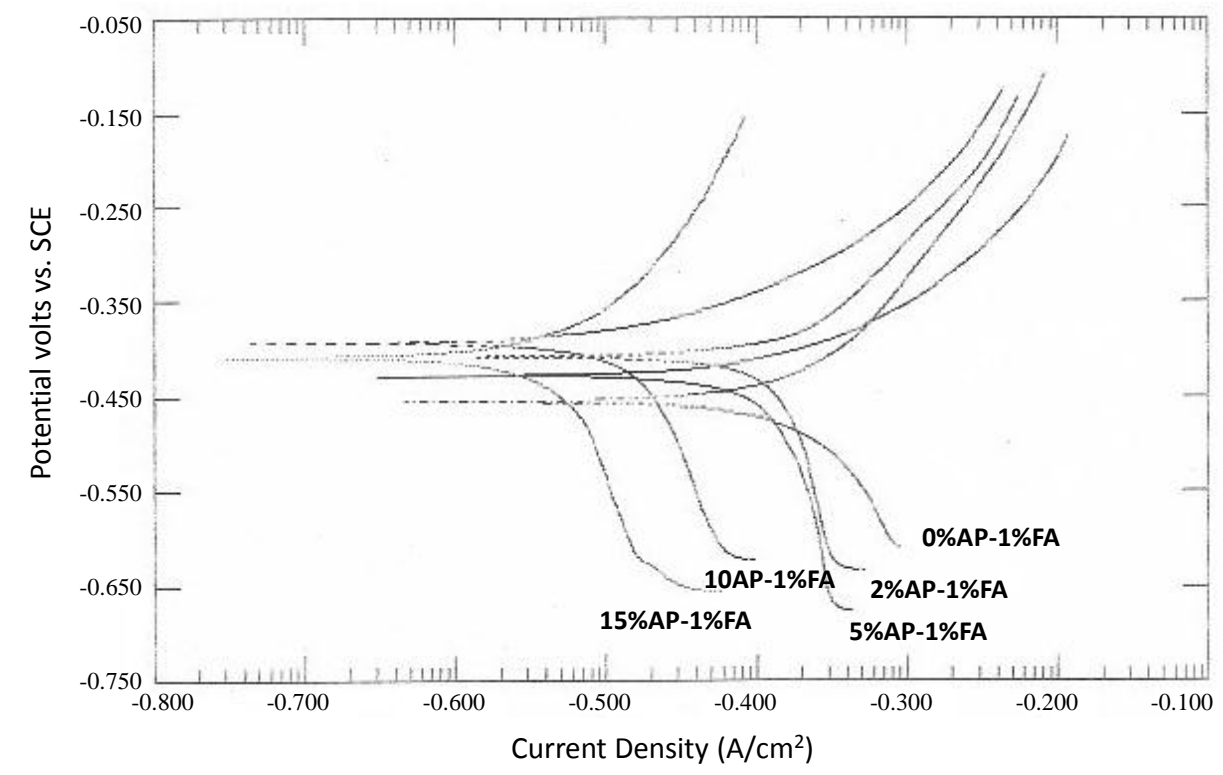

Figure 12. DC electrochemical potentiodynamic cathodic-anodic polarization diagrams for 1 wt $\%$ FA-foamed cements modified with 0, 5, 10, and $15 \mathrm{wt} \%$ AP after autoclaving at $200^{\circ} \mathrm{C}$.

Using potentiodynamic polarization curve (Figure 13), we determined the absolute corrosion rates of CS, expressed in the conventional engineering units of milli-inches per year (mpy). The Eq. (1) proposed by Stern and Geary [14] was used in the first step: $I_{c o r r}=\beta_{a} \cdot \beta_{c} / 2.303\left(\beta_{a}+\right.$ $\left.\beta_{c}\right) P_{R}(1)$; where $I_{\text {corr }}$ is the corrosion current density in $\mathrm{A} / \mathrm{cm}^{2} ; \beta_{a}$ and $\beta_{c}$ (V/decade of current) refer to the anodic and cathodic Tafel slops, respectively, which were obtained from the $\log I$ vs. $E$ plots encompassing both anodic and cathodic regions; and, $P_{R}$ is the polarization resistance which was determined from the corrosion potential, $E_{\text {corr }}$. When $I_{\text {corr }}$ was computed through Eq. (1), the corrosion rate (mpy) could be obtained from the following expression: 
Corrosion rate $=0.13 I_{\text {corr }}(\mathrm{EW}) / d$; where $\mathrm{EW}$ is the equivalent weight of the corroding CS in $\mathrm{g}$; and $d$ is the density of the corroding CS in $\mathrm{g} / \mathrm{cm}^{3}$.

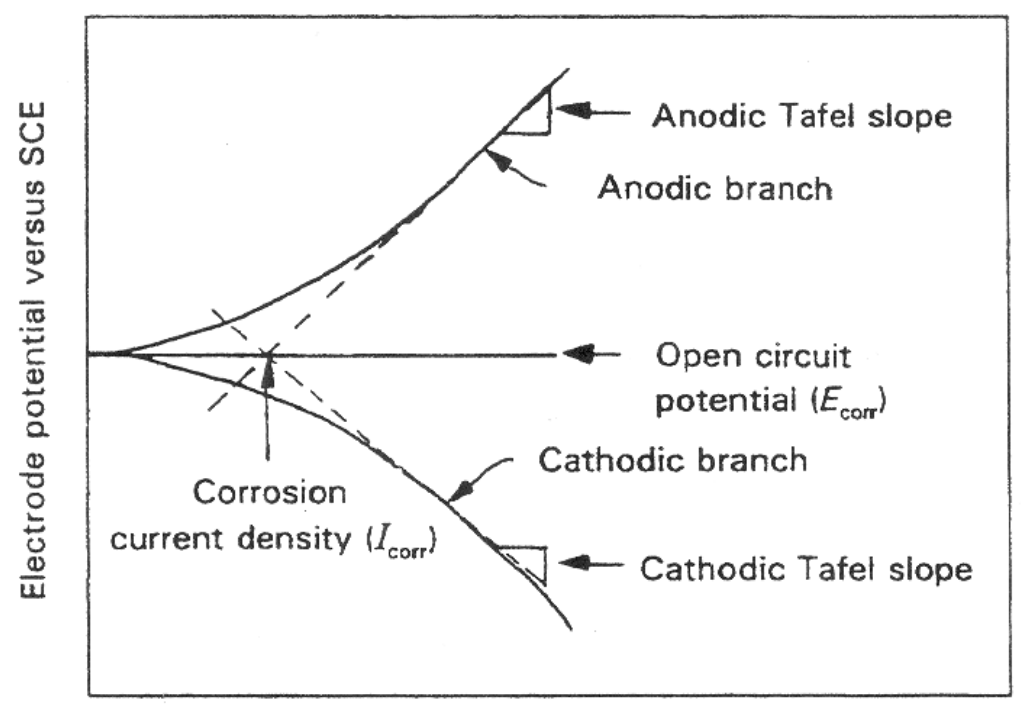

Log current density

Figure 13. Typical Tafel plot from a polarization experiment.

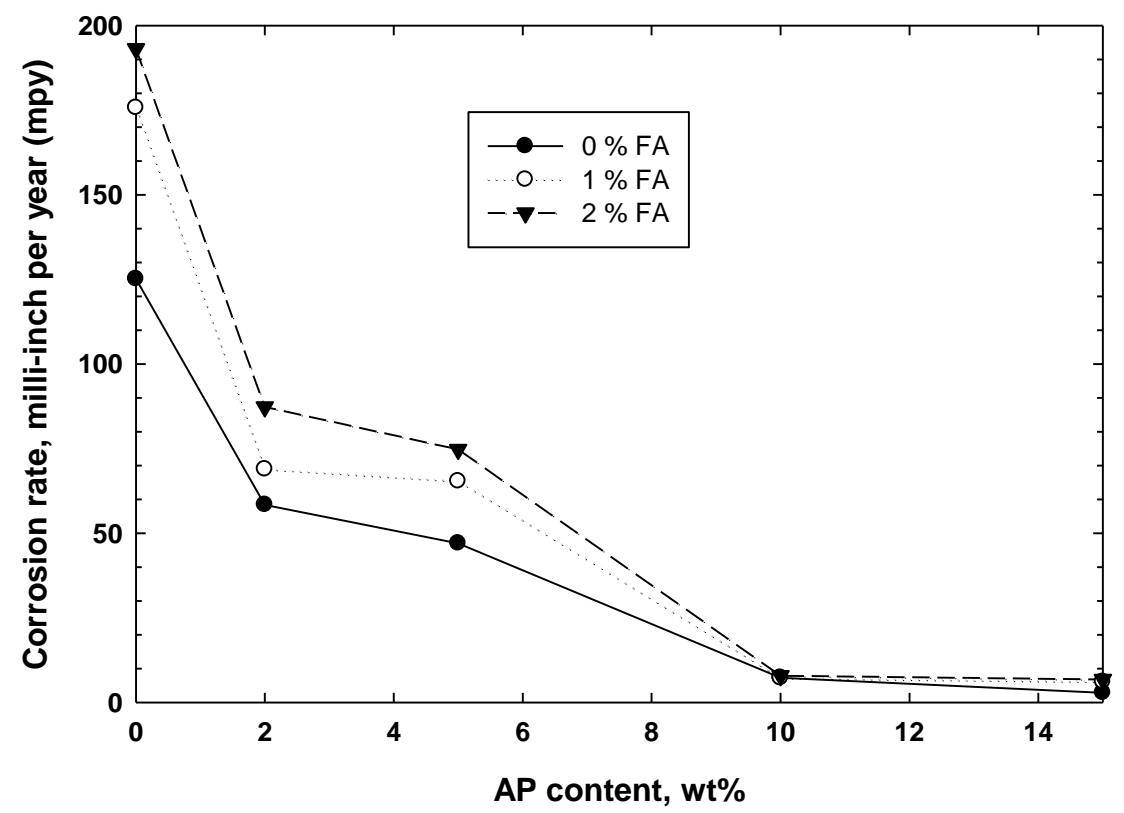

Figure 14. Changes in brine-caused corrosion rate of CS as a function of AP content in foamed and non-foamed cements. 
Figure 14 depicts the changes in corrosion rate of the CS coated with the non-foamed and foamed cements after autoclaving at $200^{\circ} \mathrm{C}$ as a function of AP content. In the AP-free coating test series, the corrosion rate of non-foamed cement was $125 \mathrm{mpy}$. This rate increased by 40 and $54 \%$ to 176 and 193 mpy when the cement was foamed with 1 and $2 \mathrm{wt} \%$ FA, respectively, suggesting that an increasing FA content impaired the efficiency of the autoclaved cement in mitigating the corrosion of CS because it engendered the formation of porous cement microstructure composed of many continuous voids. When both non-foamed and foamed cements were modified with AP, their corrosion rates drastically fell with an increasing AP content. Although its content was only $2 \mathrm{wt} \%$, the corrosion rates of 58, 69, and 87 mpy for the non-foamed, 1 and $2 \mathrm{wt} \%$ FA-foamed cements, respectively, corresponded to the reductions ranging from 2.2- and 2.6-fold, compared with those of AP-free cements. Adding $\geq 10 \mathrm{wt} \%$ AP offered a marked corrosion mitigation of less than $10 \mathrm{mpy}$ for both the non-foamed and foamed cements, verifying that AP was a potential candidate as a corrosion-inhibiting additive responsible for improving significantly the ability of foamed cements to protect the CS against the brine-caused corrosion.

\subsubsection{Adherence of foamed cement to CS}

Since a better interfacial bond between coating and CS was another factor contributing to the alleviation of the CS's corrosion, we evaluated the extent of adherence of the $2 \mathrm{wt} \%$ FA-foamed cements modified with 0,2 , and $10 \mathrm{wt} \%$ AP to CS surfaces by $\mu$ EDX elemental mapping. The testing samples were prepared in the following sequences: First, the CS corrosion coupons' surfaces were coated with AP-modified and unmodified foamed cements; second, the coated CS coupons were autoclaved at $200^{\circ} \mathrm{C}$ for 24 hours; third, the autoclaved coupons were placed on the center-loading bending apparatus to generate the tensile shear-bonding failure at the cement coating side adhering to CS, leading to the delamination of cement layer from underlying CS surface; and fourth, the interfacial CS surface side separated from the cement layer was used for $\mu$ EDX mapping. Assuming the cement is well adhered to CS surfaces and the interfacial bonding failure occurs in cement layers, our attention centered on visualizing the distribution of cementrelated Ca element that remained on CS surfaces. Thus, if we observed a widespread presence of this element, it was possible to rationalize that the cement adhered well.

Figure 15 represents the individual $\mu \mathrm{EDX}$ maps of $\mathrm{Fe}$ and $\mathrm{Ca}$ elements for interfacial $\mathrm{CS}$ surface on the sides separated from each of 0,2 , and $10 \mathrm{wt} \%$ AP-modified foamed cement layers. The $\mu \mathrm{EDX}$ analyses were conducted on the mapping area of $2.0 \times 1.5 \mathrm{~mm}\left(3.0 \mathrm{~mm}^{2}\right)$ and targeted detecting the two specific elements, Fe belonging to underlying CS and $\mathrm{Ca}$ attributed to cement. During the mapping operation, X-ray intensity counts for $\mathrm{Fe}$ and $\mathrm{Ca} K \alpha$ were recorded to create the distribution maps of these elements. On these maps the white color represents the highest $\%$ and the blue color- the lowest $\%$ of the element in the coverage. 

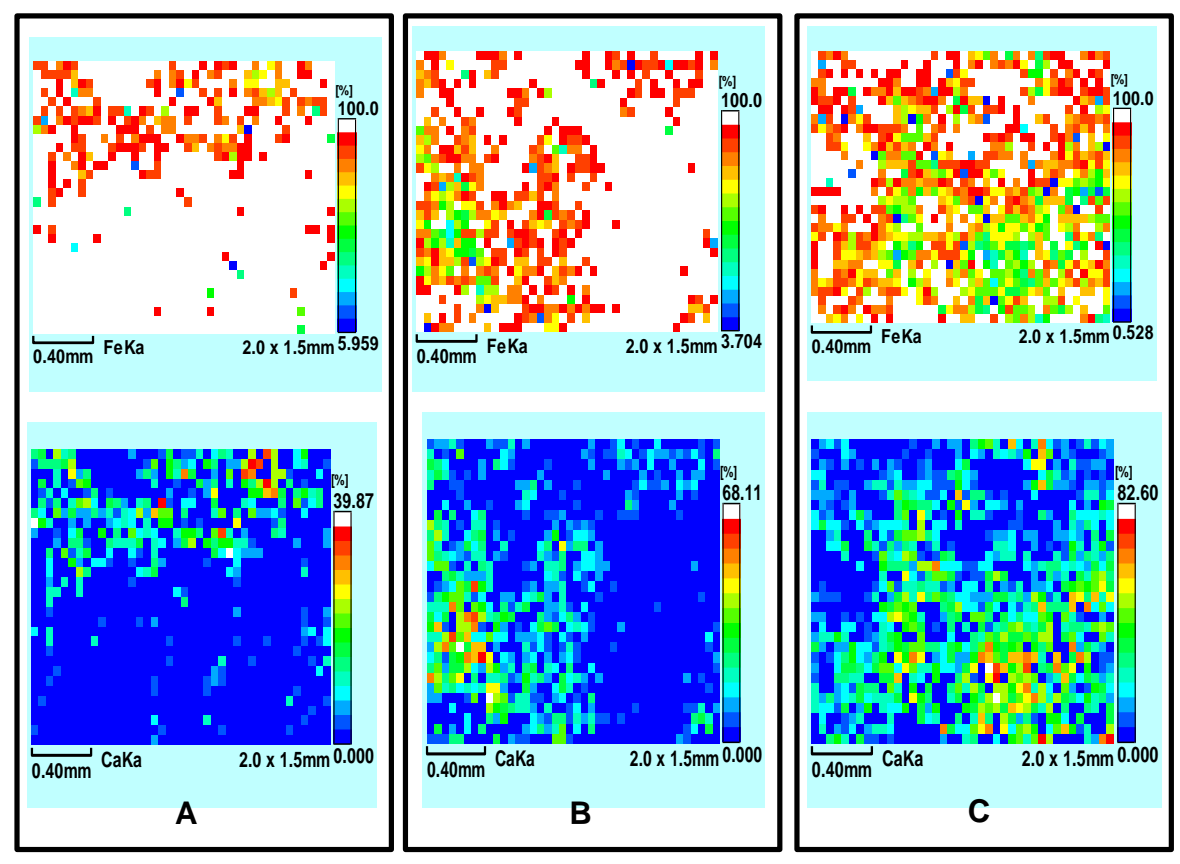

Figure 15. EDX elemental mapping of Fe (top) and Ca (bottom) for interfacial CS sides separated from foamed cements containing (A) 0, (B) 2, and (C) $10 \mathrm{wt} \%$ AP after autoclaving at $200^{\circ} \mathrm{C}$.

For the foamed cement without AP, the elemental mapping of Fe concentration revealed that there were mainly two different regions on the CS surface: The bottom one almost completely covered with $\mathrm{Fe}$ (white color, 100\% Fe) and top one with slightly lower Fe concentration (red color). Comparing to the Ca map it can be seen that the top area with lower Fe coverage had some $\mathrm{Ca}$ coverage (greenish color at the top of the Ca map). Hence, although the distribution rate of Ca element was only $39.9 \%$ per the total studied area, Ca mapping exhibited the presence of this element with a moderate concentration over the top region, signifying that some cement locally remained on the CS surface separated from the cement layer. The Ca-presence increased to $68.1 \%$, when the foamed cement was modified with $2 \mathrm{wt} \%$ AP. In fact, as seen in Fe map, a large area over the CS surface was covered by other elements coexisting with Fe, compared with that of AP-free foamed cement/CS system. More Ca can be seen at CS side removed from the 10 $\%$ AP-modified foamed cement, reflecting the Ca-concentration of $82.6 \%$. Thus, this finding obviously demonstrated the great effectiveness of AP in improving the extent of adherence of the foamed cement to $\mathrm{CS}$ in a hydrothermal environment at $200^{\circ} \mathrm{C}$. Incorporating more AP led to the development of a better interfacial bond of foamed cement to CS, thereby resulting in the interfacial bonding failure taking place in the cement layer and not at the CS-cement boundary. 


\section{Conclusion}

Using the cementitious material consisting of Secar \#80, Class F fly ash, and sodium silicate, which was designed as thermal shock-resistant cement (TSRC) in our previous work, this study was aimed at developing the corrosion-resistant foamed TSRC for carbon steel (CS) casing in the Enhanced Geothermal System (EGS) wells at hydrothermal temperature of $200^{\circ} \mathrm{C}$. To do so, the TSRC was modified with two additives, a cocamidopropyl dimethylamine oxide-based chemical compound as a foaming agent (FA) and acrylic emulsion (AE) as corrosion inhibitor. The FA employed was suitable for this cement system and served in incorporating a numerous airbubbles into the cement slurry during the blending procedure; in fact, adding of $\geq 1.0 \mathrm{wt} \% \mathrm{FA}$ conspicuously reduced the slurry's density from $1.86 \mathrm{~g} / \mathrm{cm}^{3}$ for non-foamed slurry to $\leq 1.3 \mathrm{~g} / \mathrm{cm}^{3}$ for foamed one. Lowering slurry's density decreases a risk of creating undesirable fracture zones in a weak unconsolidated rock formation by considerably reducing the hydrostatic pressure needed to circulate the slurry in the well. When the foamed slurries were modified with AE, their density depended on the content of acrylic polymer (AP) as a solid state in AE; namely, its high content caused an increased density. The content of AP was up to $5 \mathrm{wt} \%$ to sustain the ideal slurry density of $\leq 1.3 \mathrm{~g} / \mathrm{cm}^{3}$.

The acrylic acid and alkyl ester groups within the AP molecule favorably reacted with the $\mathrm{Ca}$ and $\mathrm{Na}$ cations dissociated from \#80 and sodium silicate in hydrothermal environments, leading to the formation of Ca-or Na-complexed carboxylate compounds as the hydrothermal acid-base reaction products in the cement body at $\geq 85^{\circ} \mathrm{C}$. The $\mathrm{AP}$ encompassing these reaction products withstood a hydrothermal temperature of $200^{\circ} \mathrm{C}$, ensuring that as the corrosion inhibitor it was capable of protecting the CS against corrosion at this temperature.

Both FA and AP additives altered the two important parameters of hydration reactions of \#80 and Class $\mathrm{F}$ fly ash at $85^{\circ} \mathrm{C}$ : One was reactions kinetics, the acceleration and retardation of these reactions; the other was the heat flow generated by these reactions. For the former, the FA preferentially promoted the curing reaction of \#80, rather than that of Class $\mathrm{F}$ fly ash, shortening the time to reach the onset of this reaction. Interestingly, a fast reaction of \#80 in the foamed slurry was retarded by adding AP at 2 or $5 \mathrm{wt} \%$, whereas, increasing its content to 10 or $15 \mathrm{wt} \%$ accelerated both \#80 and Class F fly ash hydration. Although there was no experimental evidence, such acceleration may be associated with the energy generated by the acid-base interactions between $\mathrm{AP}$, and $\# 80$ and sodium silicate. In the latter case, these additive acted to augment the total heat flow evolved by the combined reactions of \#80 and Class F fly ash; particularly the total amount of energy generated in the foamed slurry doubled upon addition of $10 \mathrm{wt} \%$ AP. Such enhancement of hydration reactions by AP improved the compressive-strength and-toughness of $200^{\circ} \mathrm{C}$-autoclaved foamed cements.

XRD phase study revealed that the $200^{\circ} \mathrm{C}$-autoclaved foamed cement was composed of four crystalline hydrothermal hydration reaction products, hydroxysodalite $\left[\mathrm{Na}_{4} \mathrm{Al}_{3} \mathrm{Si}_{3} \mathrm{O}_{12}(\mathrm{OH})\right]$, intermediate hydrogrossular $\left[\mathrm{Ca}_{3} \mathrm{Al}_{2} \mathrm{Si}_{2} \mathrm{O}_{8}(\mathrm{OH})_{4}\right]$, boehmite $(\gamma-\mathrm{AlOOH})$, and Si-free katoite $\left[\mathrm{Ca}_{5} \mathrm{Al}_{2}(\mathrm{OH})_{12}\right]$ phases. The first two phases were formed by hydrothermal interactions between the sodium silicate activator and Class F fly ash, while the hydrothermal hydration of \#80 led to the formation of two other phases, boehmite and Si-free katoite. These phases were responsible for strengthening the foamed cements. The same phase composition, except for the presence of 
the non-reacted sodium silicate phase, was observed from the AP-modified foamed cements, suggesting that adding AP did no significantly change the phase compositions. However, an excessive content of AP seemed to restrain the reactivity of sodium silicate.

The microstructure developed in the $200^{\circ} \mathrm{C}$-autoclaved foamed cements was characterized by disclosing the honeycomb-like porous structure made of numerous defected micro-size craters. Adding AP conferred two beneficial alterations in this microstructure: First, the defected craters were transformed to defect-free ones suggesting discrete voids; and, second, the size of craters became much smaller. Thus, the creation of defect-free, small craters was one reason why the AP-modified foamed cements developed good mechanical behavior. The other potential benefit from the presence of such advanced microstructure was the reduction in the extent of infiltration and transportation of corrosive electrolytes through the foamed cement layer, thereby mitigating the corrosion of underlying CS.

In addition, we believe that the following two specific properties of AP-modified foamed cement were a key to reducing significantly the corrosion rate of underlying CS in a brine environment: One was the formation in cements of AP film stable at $200^{\circ} \mathrm{C}$; the other was the improved adherence of the cement to CS surfaces. These two properties played an essential role in minimizing the conductivity of corrosive ionic electrolytes through the foamed cement layer, in inhibiting the cathodic reactions at corrosion sites of CS, and in increasing the coverage of CS surface by foamed cement layer. Accordingly, the corrosion rates, 125, 175, and 193 milli-inch per year (mpy), of CS for non-foamed, 1 and $2 \mathrm{wt} \%$ FA-foamed cements after autoclaving at $200^{\circ} \mathrm{C}$, respectively, were significantly reduced to 58,69 , and 87 mpy by incorporating only 2 wt\% AP. Increasing the amount of AP to $10 \mathrm{wt} \%$ led to the CS's corrosion rate of less than 10 mpy.

Based on the results, the effective amount of FA and AP to satisfying the following three material criteria, 1) the slurry density $\leq 1.3 \mathrm{~g} / \mathrm{cm}^{3}, 2$ ) the compressive strength $\geq 500 \mathrm{psi}$, and 3 ) the brine-caused corrosion rate $\leq 70 \mathrm{mpy}$ of CS, were $1 \mathrm{wt} \%$ for FA and $2 \mathrm{wt} \%$ for AP.

\section{References}

1. Sugama T, Pyatina T, and Gill S. Thermal shock-resistant cement. Geothermal Resources Council Transaction 2012; 36: 445-51.

2. Sugama T, Brothers LE, and Van de Putte TR. Air-foamed calcium aluminate phosphate cement for geothermal wells. Cem Concr Compos 2005; 27: 758-68.

3. Ann KY, Jung HS, Kim KS, Kim SS, and Moon HY. Effect of calcium nitrite-based corrosion inhibitor in preventing corrosion of embedded steel in concrete. Cem Concr Res 2006; 36: 530-35.

4. Saremi M and Mahallati E. A study on chloride-induced depassivation of mild steel in simulated concrete pore solution. Cem Concr Res 2002; 32: 1915-21.

5. Ghods P, Isgor OB, McRae GA, and Gu GP. Electrochemical investigation of chlorideinduced depassivation of black steel rebar under simulated service conditions. Corros Sci 2010; 52: 1649-59. 
6. Tang YM, Miao YF, Zuo Y, Zhang GD, and Wang CL. Corrosion behavior of steel in simulated concrete pore solutions treated with calcium silicate hydrates. Const Build Mater 2012; 30: 252-56.

7. Boga AR and Topcu IB. Influence of fly ash on corrosion resistance and chloride ion permeability of concrete. Const Build Mater 2012; 31: 258-64.

8. Hu J, Koleva DA, and van Breugel K. Corrosion performance of reinforced mortar in the presence of polymeric nano-aggregates: electrochemical behavior, surface analysis, and properties of the steel/cement past interface. J Mater Sci 2012; 47: 4981-95.

9. Wang SX, Lin WW, Ceng SA, and Zhang JQ. Corrosion inhibition of reinforcing steel by using acrylic latex. Cem Concr Res 1998; 28: 649-53.

10. Selvaraj R, Selvaraj M, and Iyer SVK. Studies on the evaluation of the performance of organic coatings used for the prevention of corrosion of steel rebars in concrete structures. Prog Org Coat 2009; 64: 454-59.

11. Sugama T. Hydrothermally self-advancing hybrid coatings for mitigating corrosion of carbon steel. Brookhaven National Laboratory 2006; BNL-77335.

12. Reardon EJ. An ion interaction model for the determination of chemical equilibrium in cement/water systems. Cem Conc Res 1990; 20: 175-92.

13. Sere PR, Armas, AR, Elsner CI, and Di Sarli AR. The surface condtion effect on adhesion and corrosion resistance of carbon steel/chlorinated rubber/artificial sea water systems. Corros Sci 1996; 38: 853-66.

14. Stern M and Geary AL. Electrochemical polarization I. A theoretical analysis of the shape of polarization curves. J. Electrochem. Soc 1975; 104: 56-62. 